\title{
Insect Herbivory in Tropical Forests
}

\author{
H. Bruce Rinker and Margaret D. Lowman
}

The degree to which insects regulate ecosystem parameters remains a key issue and one that significantly broadens the scope and value of insect ecology.

- T.D. Schowalter, Insect Ecology: An Ecosystem Approach, 2000

\section{Introduction: The Little Things that Run the World}

In $i n$ address to inaugurate the invertebrate exhibit at the National Zoo, Washington, DG on Mav 7, 1987, E.O. Wilson called insects "the little things that run the world" (Wilson 1987a). In terr ss of their diversity, distribution, and abundance, insects are unrivaled as a global ecological and evolutionary force. "It needs to be repeatedly stressed that invertebrates as a whole are even more important in the maintenance of ecosystems than are vertebrates" (Wilson 1987a). In a single tree in the Peruvian Amazon, Wilson found 43 species of ants (Wilson 1987b). Erwin (1982) discovered more than 1,000 kinds of beetles on 19 individual trees of a single species, Luehea seemannii, in a seasonal lowland forest in Panama. From this discovery, Erwin extrapolated an estimate of 30 million species of organisms on the planet (Erwin 1982, 1983). ${ }^{1}$ In terms of biomass, insects in tropical forests constitute several tons per hectare compared to a few kilograms per hectare for birds and mammals (reviewed in Dajoz 2000). Eight million ants and one million termites per hectare make up more than one-third the animal biomass in Amazonian terra firma rainforest (Hölldobler and Wilson 1990). If we limit this discussion only to their bulk in the treetops, these humble hymenopterans and associates still represent a significant portion of the total animal biomass for tropical forests. For nearly a quarter-century, we have known that canopy arthropods are key regulators of ecosystem processes (Reynolds et al. 2000). Insects then are the little things that run our forests - indeed most terrestrial ecosystems - from top to bottom.

\section{Tropical Insects: Hypotheses for Their High Biodiversity in Equatorial Forests}

Why do so many kinds of insects occur in the tropics? Numerous reasons offered in the literature (e.g., MacArthur 1969; Lowman and Nadkarni 1995; Kricher 1997; Dajoz 2000) decant into four prominent hypotheses that deal with history, structure, dynamics, and energetics. Yet each one has problematic aspects that point toward a combination of reasons for insect abundance and diversity in the tropics. As DeVries (1987) aptly wrote, "There have been many theories put forth, but none has satisfactorily answered the question, because almost all of them rely on the

\footnotetext{
'See appendix on p.38I for details about Erwin's extrapolations.
} 
circular reasoning: greater diversity generates greater diversity." Researchers may be uncertain about the reasons for the large diversity of equatorial insects, but they are confident that tropical regions are the richest reservoir of arthropod species worldwide.

The historical hypothesis focuses on long-term cnvironmental stability, thus fostering long-term diversification (Terborgh, 1992; Kricher 1997). In tropical forests, where climatic variation is low and predictable, opportunities for specialization exist, such as frugivory and unique pollination strategies (e.g., euglossine bees and canopy orchids). On the other hand, tropical areas have not been immune to climatic change. Amazonia may have endured tremendous biological uphcaval during the Pleistocene (but see Colinvaux 1997). Further, the Andes Cordillera- - notorious for its geological and climatic fluctuations - manifests extremely high endemism and biological diversity among certain taxa.

A second reason offered for high insect abundance and diversity in the tropics is the structural hypothesis (Dajoz 2000). This hypothesis states that large leaf-surface area and narrow niches promote high levels of specialization among insects, especially among phytophagous species. The brcadth of niches for herbivorous insects may be measured by their degree of hostspecificity Janzen 1983). For cxample, half the species of Lepidoptera in a Costa Rican forest feed on a single plant spccies Janzen 1983; DeVries 1987). On the other hand, contradictory data from Borneo, North America, and other locations suggest that there is a lower host-specificity in the tropics than in tempcratc regions (Mawdsley and Stork 1997)! Thus, wc cannot assert whether the elevated biodiversity of tropical arthropods is due to host-specilicity that might be higher in the tropics than in temperate regions.

The dynamics hypothesis addresses the intense competition, predation, and parasitism in the tropics that force biological radiation among insect fauna over time (see Macarthur 1972; Kricher 1997). These factors regulate the coexistence of species via ecological principles such as competitive displacement (or competitive exclusion) and put a lower ceiling on the abundance of any given species, thus allowing more species to fit in (MacArthur 1969; 1972). Yct compctition seems rare among phytophagous insects (Schowalter 2000), least observed among frce-living, chewing species and more prevalent among internal feeders (e.g., miners and borers). If competition does not structurc phytophagous insect communities, then perhaps it is not the robust Darwinian principlc as traditionally believed.

Finally, the energetics hypothesis holds that high energy diversity and resource allocation favor the cmergence of different feeding strategies (Wilson 1992; Kricher 1997). In other words, net primary productivity and species richness are highly correlated. High amounts of productivity in equatorial regions, along with the synthesis of secondary compounds in plants that deter herbivory, may drive selection toward rapid species diversification among surviving types of insects. Once again, the data are inconclusive and suggest a combination of reasons for the abundance of arthropods in the tropics.

Speculation about the basis for invertebrate diversity, however, may narrow into one simple explanation-- their small size and accompanying small niches (Wilson 1987a). An insect is necessarily small because of two physiological constraints on its body size. First, though water-soluble, its brittle chitinous exoskelcton can support only a limited mass of muscle before collapsing inward. Second, unlike the circulatory system of a vertebrate that delivers both nutriment and oxygen throughout the body, the circulatory system of an insect carries only food molecules. Oxygen is delivered separately and directly to cells via a complex system of minutc tracheae. The shell of an elephant-sized insect would shatter from gravity and stress, and its innermost tissues would die of oxygen starvation as soon as the animal exerted itself. The upper limit for body size of terrestrial arthropods seems to have been reached by the world's largest species of beetle (Titanus giganteus), moth (Thysania agrippina), wasp (Pepsis heros), scorpion (Pandinus imperator), and spider (Teraphosa leblondii) - all found in Amazonia, except for the African scorpion. "We don't know with certainty why invertebrates are so diverse, but a community held opinion is that the key is 
their small size," (Wilson 1992). Their Lilliputian size, allowing insects to divide up the environment into little domains where specialist can co-exist, seems to have guaranteed them broad ecological and evolutionary success in the tropics --and in just about every other global environment.

Borrowing from MacArthur (1969), the tropical environment is not like a box that will hold only so many eggs, but like a balloon that resists further invasion proportionally to its present contents but can always hold a little bit more if necessary. The data clearly suggest that ccological history, structure, dynamics, and energetics are all important explanations of arthropod diversity in the tropics on some level and that small size allows the metaphorical balloon to distend with Lilliputian richness.

\section{Tropical Insects: Hypotheses for Their High Biodiversity in the Rainforest Canopy}

But what accounts for the high species diversity of insects suspected in the upper canopy of equatorial forests? Basset et al. (2003) examined vertical stratification, temporal distribution, resource use, and host specificity of arthropods in tropical rainforests. The high illumination and temperature in the treetops encourage foraging and ovipositioning among insects. Leaf flush also provides a supply of young nutritious leaves that have not yct developed the defensive toughness of older leaves. On the other hand, plants often sequester secondary compounds in these same young leaves that deter herbivory. As an evolutionary barrier, phytochemicals inadvertently promote biological diversification among insects, if these arthropods metabolize the compounds and utilize the byproducts for their own survival. Canopy insects are residents of an aerial continent of sugars held aloft by stems that connect heaven to earth. Forests, like gigantic stands of lollipops, provide nutrients to those arthropods that are able to defeat the trees' attendant defensive poisons.

Intense fogging of one species of tree in Panama revealed a rich insect diversity in the rainforest canopy and led to lively speculations that this fauna is more diverse in the treetops than any other environments, including forest soils (Erwin 1982, 1983). These data are controversial, however, with speculation on sampling biases and with comparisons to recent fieldwork in other habitats (André et al. 1994; Kricher 1997; Linsenmair et al. 2001). Data from Cameroon, Guyana, and French Guiana strongly assert that invertebrate densities obtained from foliage samples in the canopy are higher than in the understory (Basset et al. 1991; Lowman et al. 1998; Linsenmair et al. 2001). Whether those densities are higher in the forest canopy than in forest soils, or in any other terrestrial habitat, is also under investigation (Reynolds et al. 2003; Rinker, in prep.). Many invertebrate herbivores, in particular, have specific food requirements that render most rainforest foliage unsuitable. Spatial/temporal phenology such as leaf flush, nectar availability, and fruiting may be the reason for aggregations of phytophages in the canopy rather than simple forest structure. Rinker et al. (2001) reviewed the ecological linkages between canopy herbivory and soil ecology, shifting emphasis away from a strict autecology of individual species toward a morc comprehensive ecosystem approach. Speculations about the high inscet diversity in forest canopies may be overstated, however, due to faulty assumptions by Erwin and others, in sampling biases, and by recent fieldwork in other habitats (André ct al. 1994; Krichen 1997; Linsenmair ct al. 2001).

\section{Plant and Insect Interactions: An Ongoing CoEvolutionary Dance for Forest Survival}

In a complex co-evolutionary dance, insects influcnce, and are influenced by, plant phytochemistry. Though there is much controversy about the magnitude and setting of global 
species-richncss on earth, the bulk of this biodiversity is found in the canopy arthropods of tropical forests (Stork et al. 1997). Tropical vegetation is renowned for its high diversity and incidence of alkaloids, latex, and other secondary mctabolites, and also for a divcrsity of counter-adaptations by phytophagous insects (Novotny et al. 2003). Of the 32 orders of insects, only nine have members that feed on living plants such as Coleoptera and Lepidoptcra (see Figure 18-1). Plants are formidable evolutionary barriers against herbivory because of their impressive arsenal of physical (e.g., toughness, trichomes, and stinging hairs) and chemical (e.g., vanilla, salicylic acid, nicotine, caffeine, tannins, and pyrethrum) defenses. Research in plant/animal interactions has bcen dominated by investigations into the role of secondary plant compounds in determining the distribution, abundance, and evolution of phytophagous insects (Hunter 1992b). For example, herbivory sometimes induces foliar changes that render leaves less suitable for the development of certain herbivorcs (Schultz and Baldwin 1982; Huffaker and Gutierrez 1999). Once the barriers are surmounted, however, phytophagous insect groups radiate extensively (see Romoser and Stoffolano 1998). Most of this complex radiation has occurred in the treetops of tropical rainforests.

Even if they survive the phytochemical barriers, insects are belcaguered by predators and parasitcs. (e.g., Romoser and Stofolano 1998, Huffaker and Gutierrez 1999; Schowaltcr 2000). Predation pressure and parasitic interactions, subject to local microclimate and structure of canopy foliage, modify the behaviors of prey species and, thereby, influence their cvolutionary development (e.g., Koike and Nagamitsu 2003); however, the latter tend to be more effective than predators in responding to and controlling eruptions of their host populatons (Schowalter 2000). In the flow of nutrients in forest ecosystems, herbivores are "midstream" components. Pressed above and below in the trophic pyramid, insects bear enormous ecological and cvolutionary weight in temperate and tropical forests. The physical and chemical defenses of plants against herbivory, plus the limiting influence of parasites and predators on insect expansion, are two important components for the long-term health of forcsts.

But a third element exists in the ever-fluctuating trophic equation. Ground measurements historically showed that phytophages typically consume about 5-10 percent of the total net primary productivity in forest ccosystems (Mattson and Addy 1975). Coincidentally, this figure makes an interesting comparison to the estimated amount of energy that reaches successivc levels in a trophic pyramid, also 10 percent (Raven and Johnson 1996). Insects in the tropics munch through an estimated $680 \mathrm{~kg} \mathrm{ha}^{-1} \mathrm{y}^{-1}$ of leaves compared to 100 to $300 \mathrm{~kg} \mathrm{ha}^{-1} \mathrm{y}^{-1}$ of leaves by vertcbrates (Dajoz 2000). Janzen (1983) examined patterns of herbivory among insects and vertebrates and concluded that leaf-cating insects are a much greater threat as defoliators of forests than vertebrate megafauna. Although 5-10 percent has been a rule of thumb for forest herbivory, the degree of defoliation can vary greatly between sites (Lowman 1987, 1995b; Schowalter 2000). Causes for this variation include phenology, agc class of leaves, vegetation strata, forest type, and the natural history of local arthropod herbivores, including the demographics of their predators and parasites. With 10 percent as a good average for the amount of organic matter that reaches a given trophic level, the remainder is dissipated as heat production and waste (Raven and Johnson 1996). And, given thcir great abundance and diversity, herbivorous insects gencratc a substantial amount of waste.

In addition to the phytochemicals and the predators/parasites, the third component of the trophic equation is frass or insect droppings. The excreta of terrestrial arthropods are "upstream" from microbes and other decomposers waiting on the forest floor. Though work has just bcgun to quantify arthropod feces in terrestrial ecosystems, it is already clear that frass plays a significant role in nutrient cycling. "The standing erop of arthropod feces has not been quantified in any terrestrial ecosystem; however, this component is much larger than any of those mentioncd previously. The standing crop of fecal pellets from macroarthropod detritivores such as millipedes may locally excecd anmual litterfall inputs" (Seastedt and Crossley 1984; sce also Ohmart et al. 


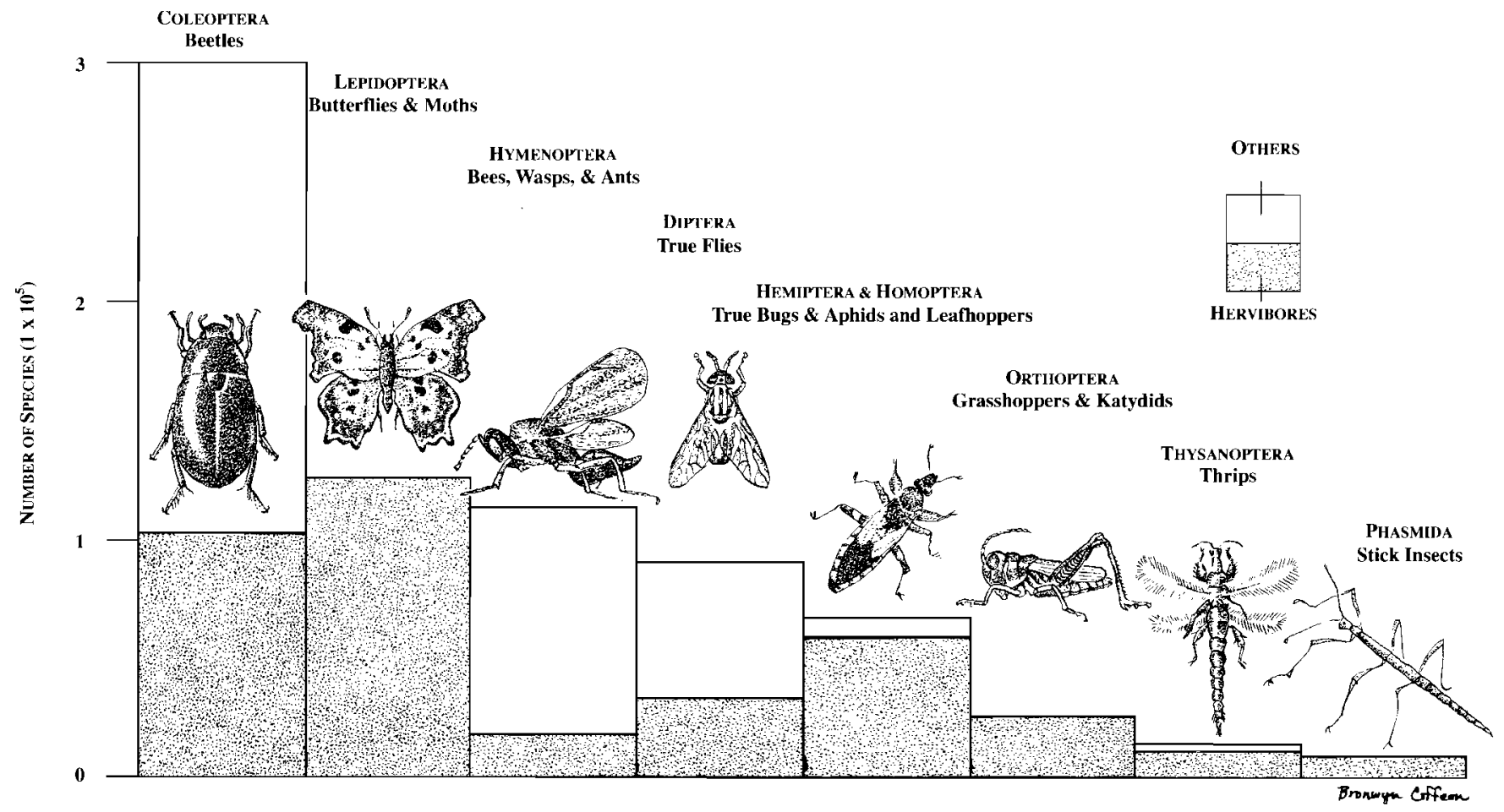

Figure 18-1 Phytophagous insect orders (from Romoser and Stoffolano 1998). Illustration by Bronwyn Coffeen and uscd with permission. 
1983). Frass then is the third component in the equation for forest survival, a product of herbivory that subsequently feeds the decomposers on the forest floor below that, in turn, nourish the forest. These ancient canopy invertebrates represent a uniting thread in the nutrient cycling through forests via the influence of their waste stream on soil processes and organisms as well their impact on phytochemistry, parasites, and predators.

\section{The Role of Herbivory in Canopy Processes}

Herbivory, the fccding on living plant parts by animals, is a key ecological process (Schowaltcr 2000) that affects all canopy components either directly (primary consumption) or indirectly (sccondary consumption). Leaves senesce and then decompose via bacteria, fungi, and microarthropods on the forest floor. Herbivory and senescence comprise pathways that link herbivory to nutrient cycling in the forest ccosystem. Foliage that is partially grazed by herbivores is called herbivory, whereas foliage that is grazed in its cntirety (or grazed extensively, leading to sencscence) is classified as defoliation. It is important to recognize that herbivory is the direct cffect of grazing whereas defoliation results in mortality that may be partially a consequence of the grazing mechanism.

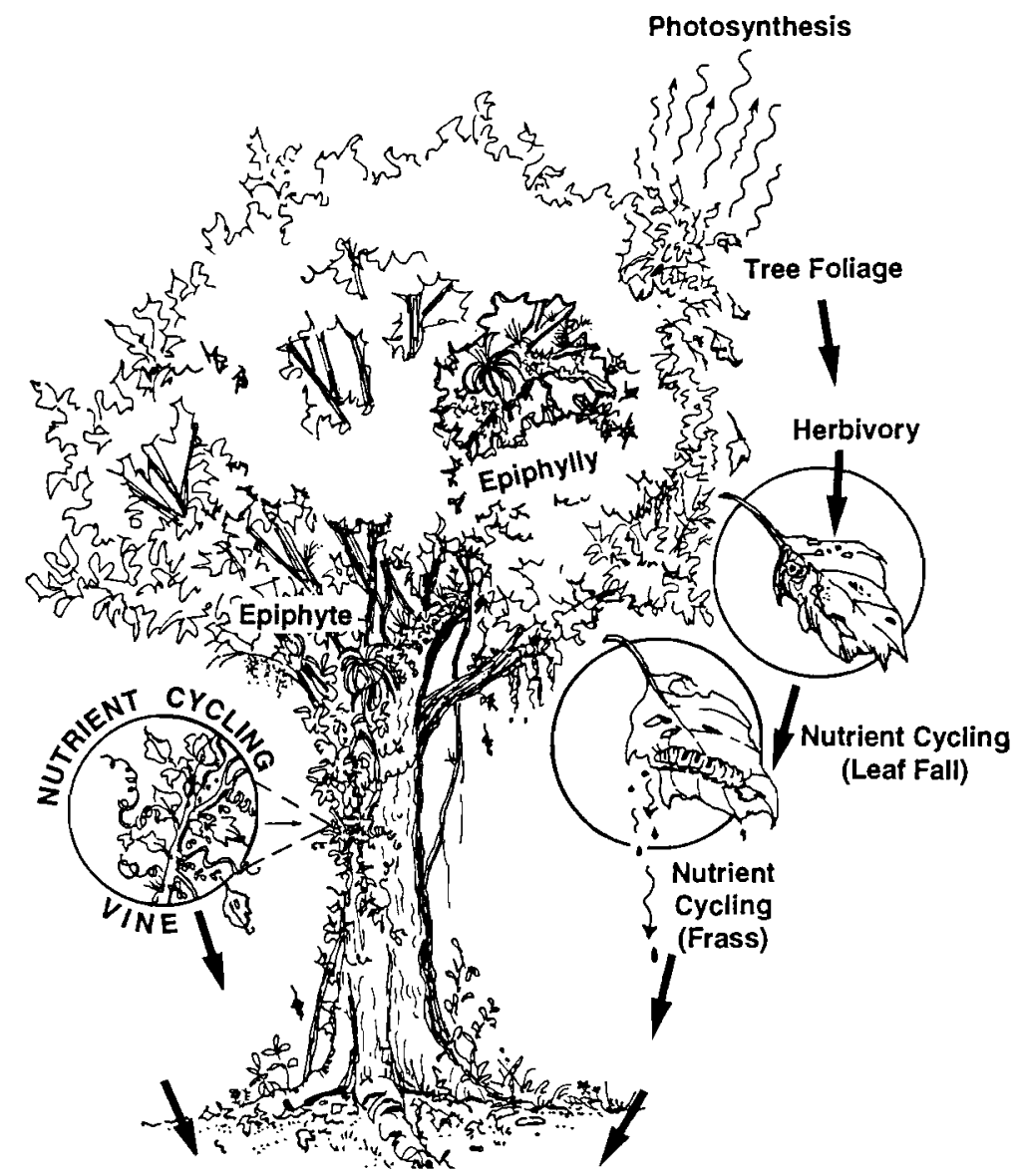

Figure 18-2 Canopy components and processes that are affected by herbivory in a forest stand (from Lowman 1995b; used with permission). 
Kristina A. Ernest

Comparing levels of herbivory among forest types poses many challenges for canopy scientists. One obvious difficulty is access into the canopy. Another is the time-consuming nature of measuring herbivory at many different spatial scales, from the leaf to the forest plot, to scale up estimates to the forest stand (Lowman 1985). To complicate matters, researchers have used a variety of approaches to measuring herbivory rather than using a single standardized protocol (Lowman 1995; Lowman 2001). To help solve these problems, a team of canopy researchers with diverse expertise (David C. Shaw, H. Bruce Rinker, Margaret D. Lowman, and myself) joined forces. We developed a novel technique for estimating the levels of herbivory in forest stands by sampling random locations within the three-dimensional canopy space of a forest (see Figure 1). This three-dimensional randomization avoids the complicated sub-sampling imposed by the traditional method of scaling up. For each randomly chosen XYZ coordinate with accessible foliage of any vascular plant species, we measured percent of leaf area consumed by herbivores on 10 randomly chosen leaves (or 50 conifer needles) within a $25 \times 25 \times 25 \mathrm{~cm}$ subplot (see Figure 2). Canopy cranes provided us rapid access to these sample locations. We tested this new method in two structurally and functionally dissimilar forests (tropical rainforest at Cape Tribulation, Queensland, Australia, and temperate conifer forest at Wind River, WA, USA).

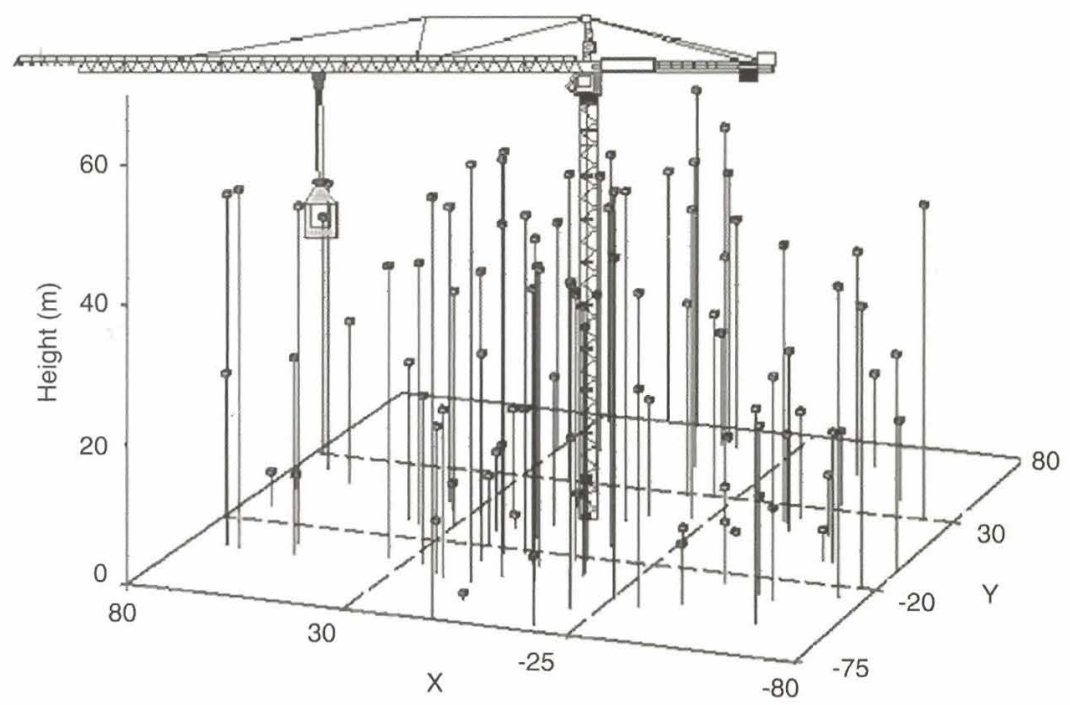

Figure 1 Spatial distribution of 104 actual sample locations at Wind River, WA.

We recorded an average herbivory level of 8.6 percent for 93 sample locations in tropical rainforest at the Australian Canopy Crane site, compared with 1.6 percent for 104 sample locations in temperate conifer forest at the Wind River Canopy Crane Research Facility. Although this method has limitations (e.g., not all random locations are accessible from the gondola of the crane), the advantage of fairly rapid access to all vertical 


\section{MEASURING FOREST HERBIVORY LEVELS USING CANOPY CRANES-cont'd}

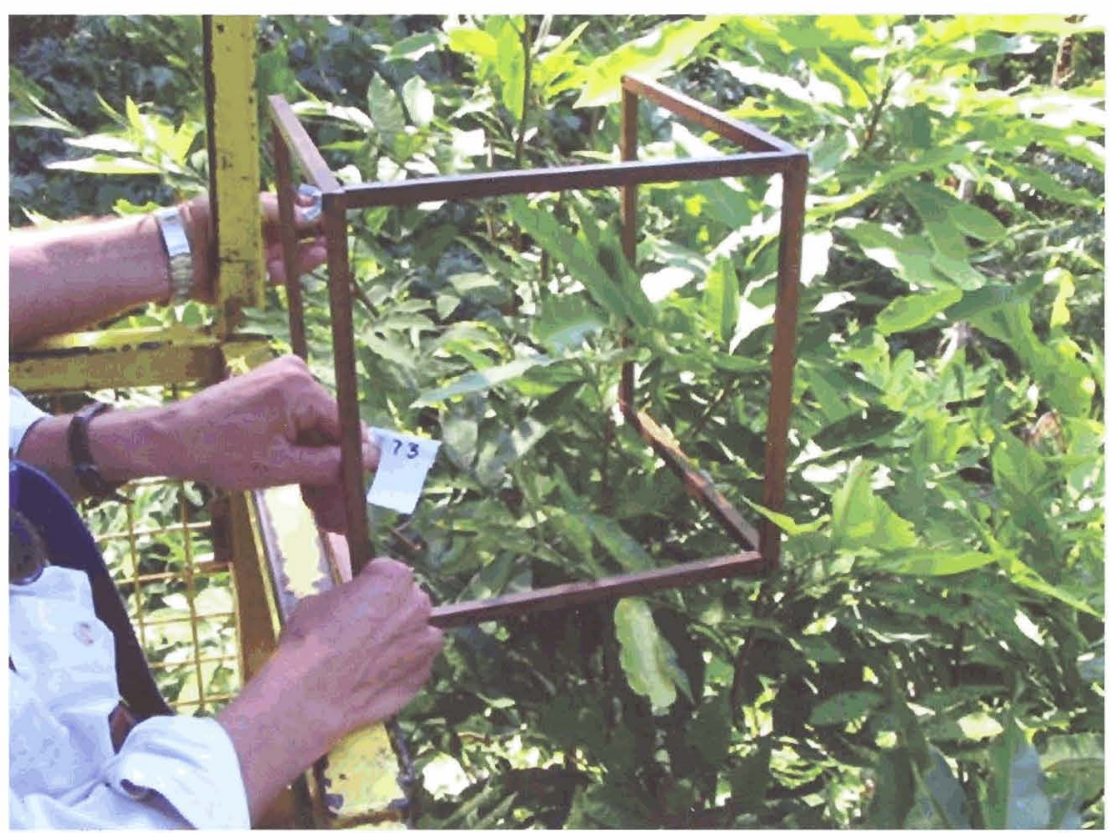

Figure 2 Subplot $(25 \times 25 \times 25 \mathrm{~cm})$ to randomly sample 10 leaves (or 50 needles) at each sample location. Photograph by D. Shaw.

levels within the forest allows researchers at any canopy crane site to compare forest stands around the globe in a standardized way.

We believe this method has the potential to make important advances in forest and herbivory research. First, we hope it will become a standard protocol for rapidly assessing the extent of herbivory in forest stands, and we plan to apply it at all canopy crane sites. Second, data collected using this protocol will help set baseline numbers for one of the key processes regulating ecosystem function. Primary productivity may be regulated by herbivory, yet we sorely lack measurements of herbivory at the stand level due to the difficulty in logistics and the extensive sampling required. Additionally, global climate change and increasing atmospheric $\mathrm{CO}_{2}$ are likely to affect rates of herbivory (Coley 1998; McNaughton 2001). Standardized, quantitative data on rates of herbivory can be used in predictive models about how forest productivity will change under future climate scenarios.

\section{References}

Coley, P.D. (1998). Possible effects of climate change on plant/herbivore interactions in moist tropical forests. Climatic Change 39, 455-472.

Lowman, M.D. (1985). Temporal and spatial variability in insect grazing of the canopies of five Australian rainforest tree species. Austratian Journal of Ecology 10, 7-24.

Lowman, M.D. (1995). Herbivory as a canopy process in rain forest trees. In "Forest Canopies" (M.D. Lowman and N.M. Nadkarni, Eds.), pp. 431-455. Academic Press, San Diego.

Lowman, M.D. (2001). Plants in the forest canopy: some reflections on current research and future direction. Plant Ecology 153, 3950.

McNaughton, S.J. (2001). Herbivory and trophic interactions. In "Terrestrial Global Productivity" J. Roy, B. Saugier, and H.A. Mooney, Eds.), pp. 101-122. Academic Press, San Diego. 
The study of herbivory as an integrated process throughout a forest stand requires information on many aspects of forest biology including plant phenology, demography of insect populations, leaf growth dynamics, tree architecture, foliage quality and density, physical environment, nutrient cycling, and plant succession. Interest in insect-plant relationships has emphasized interactions among a few species rather than within an entire ccosystem. It has also centered on studies of shrubs and herbaceous plants. Few studies exist on insect-tree interactions, and even fewer involving forest stands. Yet forest canopies comprise an ccological arena where some of the most complex insect-plant interactions occur in terms of spatial, taxonomic, and structural factors.

The consumption of plant materials by herbivores is a subject of great cconomic and ecological importance (Barbosa and Schultz 1987; Price et al. 1991; Schowalter 2000; Ribeiro 2003). Because forest canopies contain the bulk of terrestrial photosynthetic material involved in the maintenance of global biogeochemical cycles (e.g., carbon dioxide sequestering), the processes affecting canopy foliage have dircet consequences on the health of our planet. Leaf predation is an example of herbivory. The loss of foliage by insect predators can occur by direct consumption or by less obvious impacts such as leaf mining, sap-sucking, and leaf tying. Herbivory affects foliage during all stages in the life of a leaf; over time, plants respond accordingly with the evolution of defenses against predation. Levels of herbivory range from negligible grazing to mortality of leaves, branches, whole crowns, and entire forest stands.

Herbivore populations fluctuate in the canopy and, in turn, affect the populations of other invertebrates and of vertebrates such as birds and mammals that feed on the herbivorous organisms (e.g., Woinarski and Cullen 1984). This fluctuation rcsults from a legion of systcm variables including weather (Readshaw 1965), disturbances (Smith 1982), historical processes (Southwood 1961), topography (Ward 1979), tree density (Morrow and Fox 1980), plant structure (Lawton and Schröder 1977), plant secondary compounds (Macauley and Fox 1980), or even random processes (Clark 1962). Stand growth and dynamics may ultimately be affected by herbivory and by the susceptibility of a species to grazing (revicwed in Schowalter et al. 1986). The impact of leaf consumption on herbs, sccdlings, and shrubs has been quantified in terms of mortality, succcssion, and compensatory growth (Lowman 1982; Colcy 1983; Marquis 1991). Such factors are more difficult to measure for tall trees and across forest stands. Examples of herbivory that have been integrated with other aspects of forest dynamics include studies on the spatial distribution of canopy insect populations in the Australian rainforest tree Argyrodendron actinophyllum (Basset 1991), nutrient cycling via frassfall or litterfall pathways (Lowman 1988), pest outbreaks and stand mortality (Lowman and Heatwole 1992), and herbivory in relation to stand phenology (Schultz and Baldwin 1982). Underlying the variability between insect taxa and locations are discernible patterns to phytophagous insect distribution (Woinarski and Cullen 1984).

\section{History of Herbivory Studies in Forest Canopies}

Forests are not vast expanses of homogeneous green tissue. As we walk through woodlands, we usually focus our obscrvations on a narrow band of foliage from ground level to $2 \mathrm{~m}$ in height. This represents, at most, 10 percent of the plant life in mature forests with the majority high above our heads and normally beyond our immediate observations. Bccause herbivore-plant interactions occur in the foliage, herbivory as a forest process remained relatively unknown until we developed safe and effieient methods of canopy access. Today we may best view forests, not as uniform expanses of green, but as mosaics of holes in leaves (Lowman 1995b).

Historically, most herbivory studies involved the measurement of levels of defoliation in forests at one point in time. Foliage was sampled typically near the ground level in temperate deciduous forcsts where annual losses of 3 to 10 percent leaf surface area were reported (Bray 1964; 
Bray and Gorham 1964; Landsberg and Ohmart 1989). Most studies were extrapolated, however, to evergreen rainforests for three reasons: temperate deciduous forests have a comparatively simple phenology with an annual turnover of leaves; measurements were sometimes made from senescent leaves retrieved from the forest floor; and replicated stratificd sampling was rarcly attempted. In short, defoliation was treated as a discreet snapshot event (Diamond 1986), accounting for neither temporal nor spatial variability.

More recent studies expanded in scope to include temporal and spatial factors to explain the heterogeneity of herbivory throughout the canopy. There are five noteworthy discoveries in the history of herbivory research:

1. An important attribute affecting levels of foliage consumption is age of leaf tissue with soft, young leaves preferred over old, tough leaves (Coley 1983; Lowman 1985).

2. The most abundant herbivores in forests are insects in terms of both numbers and estimated impacts (reviewed in Schowalter et al. 1986; Lowman and Moffett 1993). In some ecosystcms, however, mammals arc also important (e.g., monkeys, koalas, and trec kangaroos, as revicwed in Montgomery 1978).

3. Canopy grazing levels are hetcrogeneous befween forests, ranging from negligible losses to total foliage losses, and within forests, varying with plant and herbivore species, height, light regions, phenology, age of leaves, and individual crown (Lowman 1992).

4. 'The assumptions common in the 1960s (i.e., that herbivory averaged 5 to 10 percent annual leaf area loss and was homogencous throughout forests) were oversimplified and underestimated, particularly for evergrecn forests (e.g., Fox and Morrow 1983).

5. Foliagc fecders are featured in the ecological literaturc as the most common type of herbivore. Sapsuckers may also be important, however, although they have not been as well studied. Reputedly, foliage consumption is easier to measure than sap consumption yet, even for measurement of folivory, standard protocols are not well established (see Lowman 1984).

These discoverics were facilitated by the development of efficient and safe access methods that expanded the scope of foliage sampling into the canopy. Subsequently, studies of herbivory in cvergreen tropical forcsts increased and revealcd the heterogeneous nature of plant/animal interactions.

\section{A Comparison of Forest Herbivory}

The texture, age class, and nutritional value of lcaves vary considerably within and between individual trees. Phenological events, along with species composition and rarity along a latitudinal

Table 18-1 Stand-Level Herbivory (\%) in Forests around the World

\begin{tabular}{ll}
\hline Forest Type & $\%$ Herbivory \\
\hline Australian Dry Forest & 15 to $300 \%$ (Lowman and Heatwole 199\%) \\
Australian Wet lorest & $8.6 \%$ (Staw, Emest, Rinker, and Jowman, pers. comm.) \\
Temperate Deciduous Forest & $15 \%$ (Lowman 1999) \\
Pacific Northwest & $1.6 \%$ (Shaw, Ernest, Rinker, and Lowman, pers. comm.) \\
Ciloud Forest & $26 \%$ (Lowman 1992) \\
Subtropical Forest & $16 \%$ (Lowman 1987) \\
Warm lemperatc Forest & $21 \%$ (Lowman 1987) \\
Tropical Forcst & 12 to 30\% (Lowman 1995a) \\
\hline
\end{tabular}


gradient, likewise fluctuate. All thesc variables result in patchy susceptibilities of trecs to insect herbivorcs. Consequently, forest canopies support complex assemblages of phytophagous insects, usually inconspicuous except when population outbreaks produce widespread defoliation (Schowalter et al. 1986; Reynolds et al. 2000; Linsenmair et al. 2001). Herbivory studies that measure defoliation at a single point in time, historically the most common type of research (Lowman 1995b), provide only a limited window of understanding for plant-animal interactions in forests. The complex temporal and spatial patterns of leaves in forest canopies then neccssitate long-term approaches to studies of insect herbivory.

Herbivory in canopies ranges from 1 to 5 percent of total leaf area production in temperatc forests (Schowalter et al. 1981) to more than 300 percent in Australian eucalypt forests where trees re-foliated several successive times after lcaf loss (Lowman 1992; Lowman and Heatwole 1992). Several studies (e.g., Seastedt and Crossley 1984; Lowman et al. 1998) and literature revicws (e.g., Schowalter et al. 1986; Lowman 1995b; Schowalter 2000) give details on herbivory rates at specific sites in tropical areas. Table 18-1 provides a summary of two researchers' fieldwork.

Arthropods are the most abundant herbivores in many tcrrestrial ecosystems (Erwin 1983; Seastedt and Crossley 1984; Lowman and Morrow 1998). Of the nine herbivorous insect orders, the three most important leaf-consuming taxonomic groups are Coleoptera (beetles), Lepidoptcra (butterflics and moths), and Hymenoptera (bees, wasps, and ants) (Reichle ct al. 1973; Lowman and Morrow 1998). The capacity of their populations to cause rapid, often dramatic change in forest dynamics such as tree growth and survival, evapotranspiration, and nutrient cycling speaks unequivocally about the significance of their connections to overall ecological processes (Schowalter 2000). Surprisingly, those links are poorly understood, especially those that connect forest canopies to forest soils.

Herbivory lcvels vary significantly betwcen species and between forest types, as illustrated by long-term studies in Australian rainforests (sce Figure 18-3). Lowman (1982) originally hypothesized that evergreen forests with lower diversity would have higher herbivory lcvels than neighboring evergreen forests with higher diversity. The cool temperate rainforcst, where Nolhofagus moorei dominated over 75 percent of the canopy, averaged an annual 26 percent leaf area loss to grazing insects (Selman and Lowman 1983). The majority of this was due to a host-specific chrysomelid beetle that fed exclusively on the young leaves of $N$. moorei during the spring flush. In contrast, the subtropical rainforests, where no species occupicd morc than 5 percent of the canopy within a stand (Lowman 1985), averaged only 15 percent annual leaf area loss to insect grazers. Herbivory also varied significantly among species. Toona australis (Meliaceae), which is relatively rare and is annually deciduous, average less than 5 percent loss, whereas neighboring canopies of Dendrocnide excelsa (Urticaceae) that colonizes gaps averaged over 40 percent annual leaf loss (Lowman 1992).

In addition to variation in grazing levels between spccics and stands, herbivory is variable within individual crowns. The heterogeneity of defoliation is a consequence of a lcaf's cnvironment and phenology with different leaf cohorts exhibiting different susccptibilities to grazing (sensu Whittam 1981). From long-term studies, Lowman successfully pinpointcd "hot spots" in the canopy where grazing was high (see Figure 18-4). These hot spots included areas of predictable susceptibility to herbivores such as new leaf flushes, soft tissues for colonization, low shade regions of the canopy where insects aggregate to feed in the absence of predators, and canopy rcgions with flowers, epiphytes, and vines (Lowman 1992; Lowman et al. 1993). Long-term mcasurcments of Nothofagus moorei (Nothofagaceae) showed crowns that exhibited different grazing lcvels with leaf age, different stands, and time (Selman and Lowman 1983). Nothofagus moorei had approximatcly eight cohorts of leaves present in the canopy at one point in time (see Figure 18-5), cach with varying levels of susceptibility to insect attack. Young lcaves that emerged during the spring 


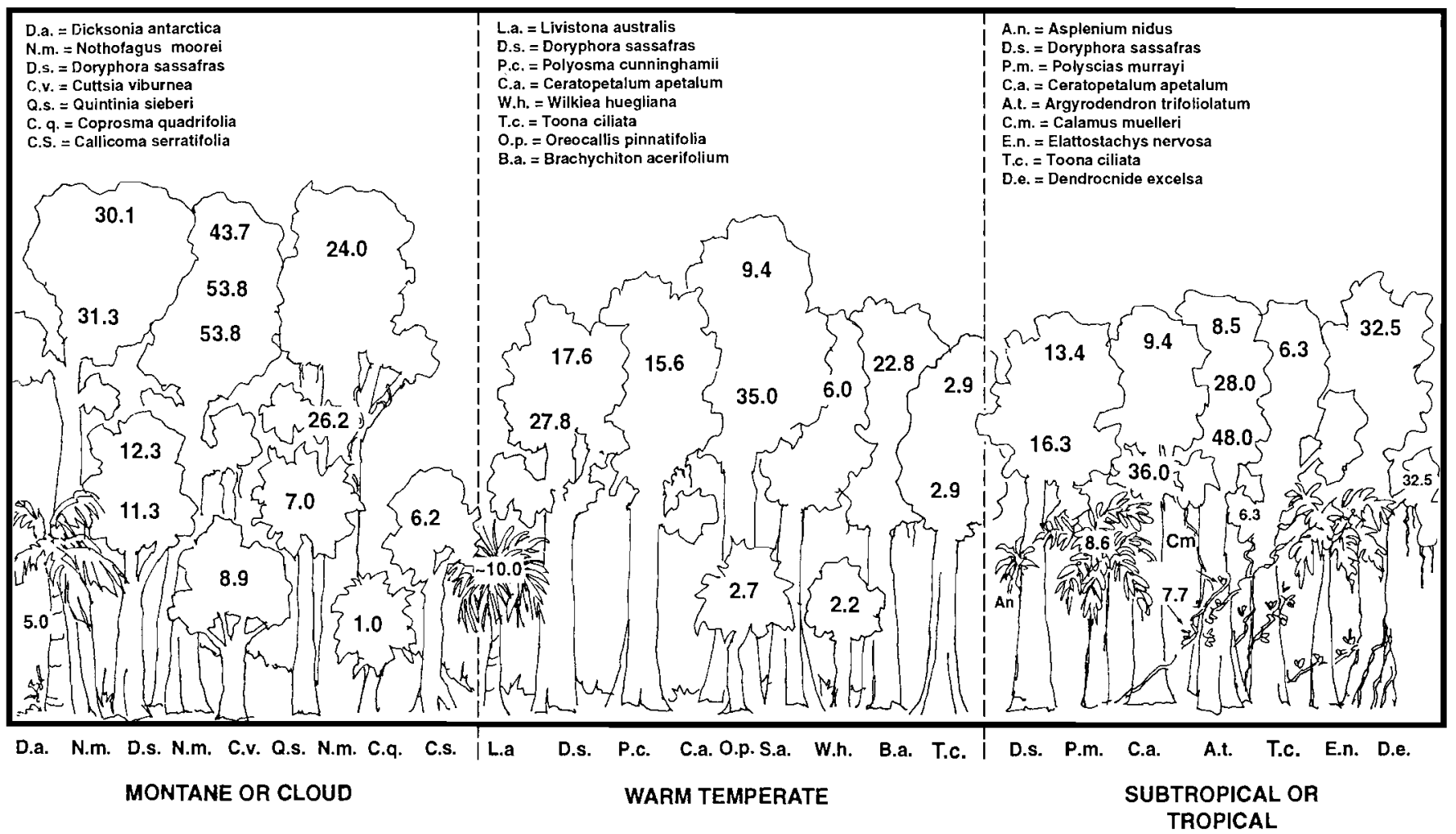

Figure 18-3 Variation in herbivory between species, heights, and sites along an elevational gradient in Australia (from Lowman 1995b; used with permission). 


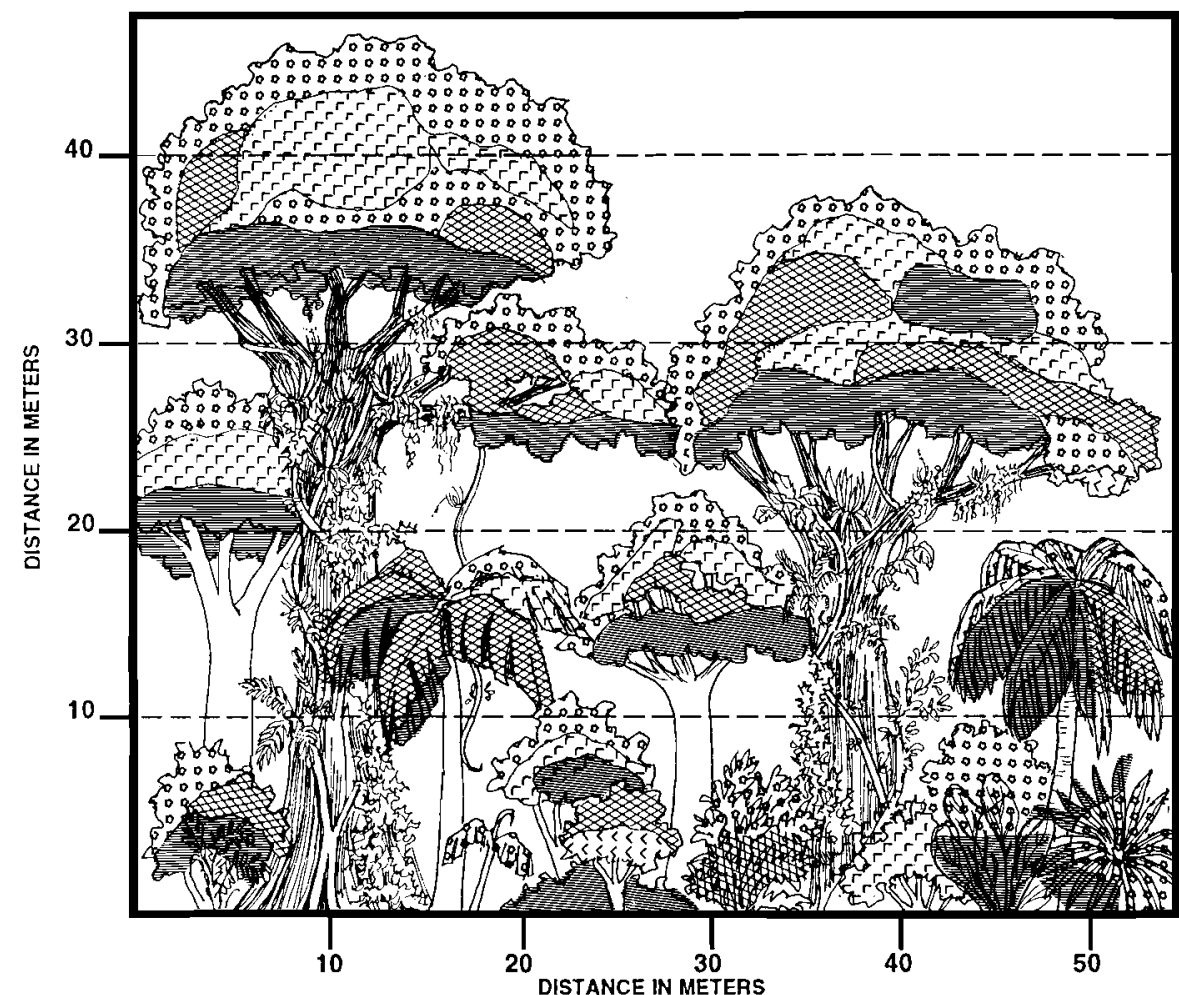

\section{FACTORS:}

HEIGHT

LIGHT

SPECIES

INDIVIDUALS

AGE - leaves

- plants

SITE

LEGEND

DENSITY

DIVERSITY

HUMAN

ACTIVITY

\section{HIGH HERBIVORY}

LOW LEAF GROWTH

rr. HIGH HERBIVORY GROWTH

MODERATE HERBIVORY

MODERATE LEAF GROWTH

OO LOW HERBIVORY

HIGH LEAF GROWTH

NEGLIGIBLE GROWTH

\& HERBIVORY

Figure 18-4 Schematic representation of canopy "hot spots" where herbivores are attracted to susceptible foliage (from Lowman 1995b; uscd with permission). 


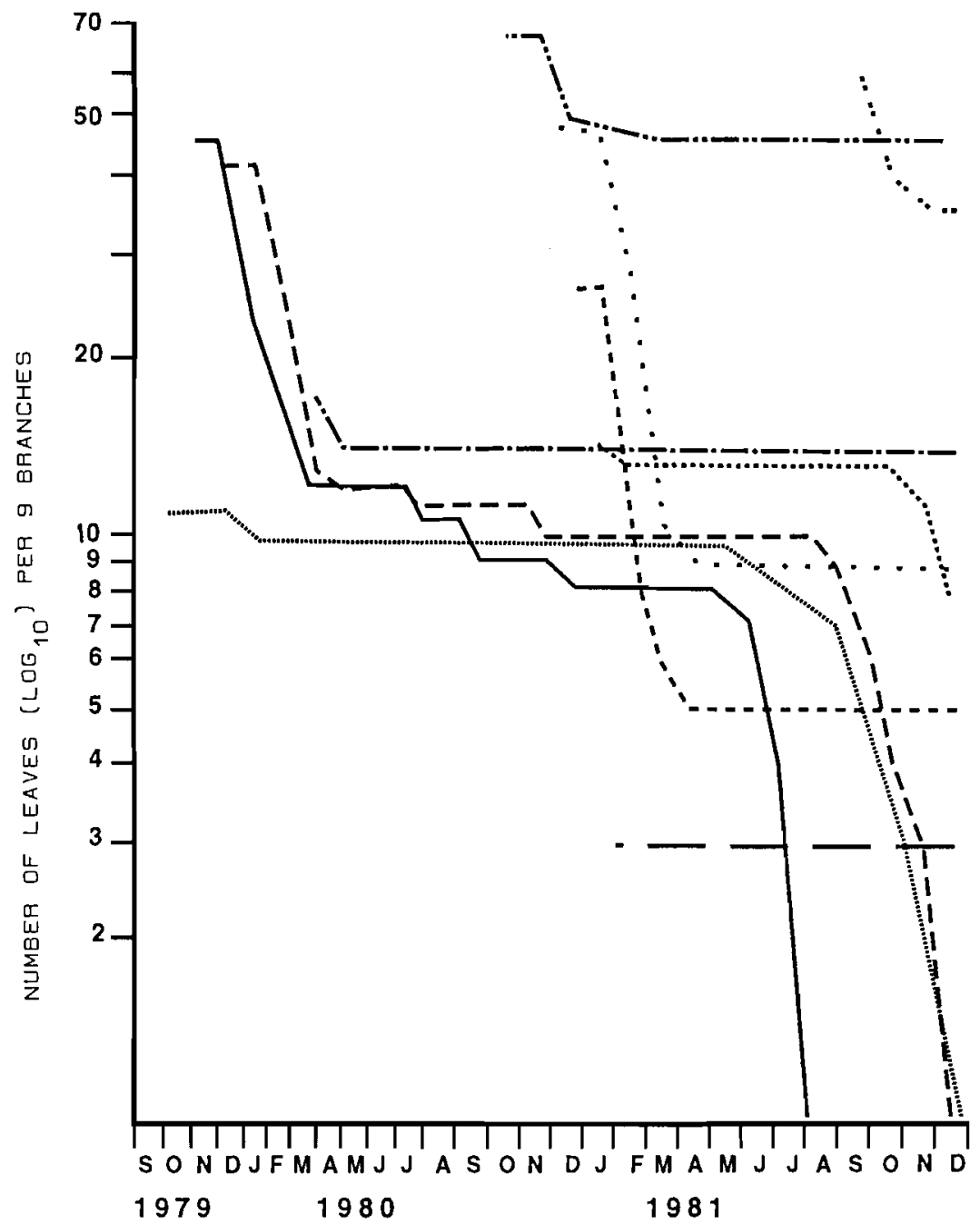

Figure 18-5 Leal survivorship curves for leaves of Nothofagus moorei (Fagaceac) in Australia's cool temperate rainforests during a two-ycar period (September 1979 to September 1981), cxpressed on a $\log _{10}$ scale (from Lowman 1995 b; uscd with permission).

(October and November) were the most preferred by the beetle larvae that emerged synchronously with flushing, whereas old leaves (greater than one year) from summer flushes and from the previous year were highly resistant to grazing. In addition, herbivory varied significantly between branches and individual crowns but not with light regimen or height (Selman and Lowman 1983).

More comparisons between forests are needed to understand the impact of herbivory on these ecosystems, though some progress was made during the last decade or so. For example, the annual levels of defoliation in Australian trees ranged from as low as 8 to 15 percent in subtropical rainforests to as high as 300 percent in dry sclerophyll (Eucalyptus spp.) stands (Lowman 1992; Lowman and Heatwole 1992). In this case, different mechanisms arc clcarly regulating insect defoliators and subsequent foliage responses in two forests. Gentry (1990) cited the need for comparisons between Central and South American forests as the stimulus for a symposium sponsored by the Association for Tropical Biology and his subsequent production of a volumc 
on four neotropical forests. Similarly, a session for the American Institute of Biological Sciences was held to stimulate comparisons between ncotropical and paleotropical forests (Lowman 1993). The prospect of increased ecological comparisons between forests, especially from different floristic zones, is an incentive to develop better protocols for field-sampling of events such as insect grazing. What species are appropriate to sample? Is there greater variation within or betwcen forests? And how do we tackle these questions with statistical and biological rigor?

\section{Herbivores as Mediators of Forest Processes}

Herbivores have a variety of dircet and indirect effects on plant communities (Seastcdt and Crossley 1984; Ritchie et al. 1998). By consuming plant material, herbivores influence decomposition and nutrient cycling in communities (Pitelka 1964; Schultz 1964; Kitchell et al. 1979; Swank et al. 1981; Pastor and Cohen 1997). Experimental studies have confirmed the role of vertcbrate herbivores as mediators of decomposition processes in terrestrial systems (McInncs et al. 1992; Molvar et al. 1993; Pastor et al. 1993; Ritchic ct al. 1998). Both empirical (Rucss and Scagle 1994; Lovett and Ruesink 1995) and thcorctical studies (Loreau 1995; Dc Mazancourt et al. 1998; De Mazancourt and Loreau 2000) suggest that herbivory, by both vertebrates and invertebrates, can have significant effects on the rates of decomposition and nutrient availability in soils.

Canopy processes (e.g., herbivory and defoliation) are coupled to forest floor processes (e.g., decomposition) through inputs of leaf and twig litter, canopy throughfall, and frass, the excretory products of insect digestion (Schowalter and Sabin 1991; Schowalter et al. 1991; Lovett and Ruesink 1995). Defoliation by insects in forests may impact primary productivity and nutrient cycling (Mattson and Addy 1975; Kitchell et al. 1979). Phytophagous insects in forcst canopies drop materials into the soil community through two major pathways. First, defoliators introduce frass, greenfall (fragmented leaf tissue dropped during herbivory), and leaves abscised prematurely to the forest floor (e.g., Risley and Crossley 1993). Second, throughfall (rainwater modified by its passage through the forest canopy) is altered by the combination of dissolved frass and modified leachates from damaged leaves (e.g., Stadler and Michalzik 2000; Reynolds and Hunter 2001). These pathways combine to introduce increased amounts of carbon $(\mathrm{C})$, nitrogen $(\mathrm{N})$, and phosphorus (P) into the soil community (Reynolds ct al. 2000; Reynolds and Hunter 2001). Increased activity by mitcs and springtails, comminuting these herbivore-derived inputs in the soil, will result in increased levels of decomposition.

Wilson (1987a) argued forcibly that insects in forests are vital components of the ecosystcm with effects more pronounced than those of vertebrates. Although the impact of insects on forest systems is controversial (Terborgh 1988), it remains largely untested. A considerable proportion of forcst canopies can be turned over annually by insect-herbivores (Lowman 1992), yet the consequences of herbivory for decomposers such as soil mesofauna are largcly unexplored. Schowalter and Sabin (1991) reported increases in litter arthropod diversity and abundance following defoliation of saplings in a 10-ycar-old Douglas-fir forest, but the effects of defoliator inputs were not distinguished from defoliator-induced changes in microclimate.

As mentioned previously, evidence exists that herbivory can influence soil processes. Inscet grazing can actually enhance nitrogen export from forest ecosystems (Swank et al. 1981; Reynolds et al. 2000). Low to moderate defoliation lcvels by forest insects can have significant effects on nutrient cycling (Schowalter et al. 1991). Some evidence suggests that nitrogen is immobilized in frass by fungal decomposers (Lovett and Rucsink 1995), although a field test of nitrogen dynamics following defoliation is sorely needed (Lerdau 1996). Likewise, the cvidence is strong that defoliation influences the chemistry of throughfall (Scastcdt and Crossley 1984; 


\section{THE LEIPZIG CANOPY CRANE PROJECT: BIODIVERSITY, ECOLOGY, AND FUNCTION IN A TEMPERATE DECIDUOUS FOREST}

Wilfried Morawetz and Peter J. Horchler

The last decades' run on the biological investigation of forest canopies rarely included longterm studies on biodiversity in temperate forests. One exception is the Leipzig Canopy Crane Project, situated in a species-rich, near-natural deciduous forest in central-eastern Germany (Morawetz and Horchler 2002). The tower crane (Liebherr 71 EG), established in 2001, runs on rail tracks $120 \mathrm{~m}$ long (see Figure 1).

With its 45-m long jib, it covers an area of approximately 1.6 ha. With a gondola, scientists can reach almost any site in the three-dimensional forest space up to a height of 32 $\mathrm{m}$. The project aims to identify spatio-temporal patterns of biodiversity and to link them functionally to environmental factors such as structure and microclimate. Since it is still in the pilot phase, only preliminary results are reported here.

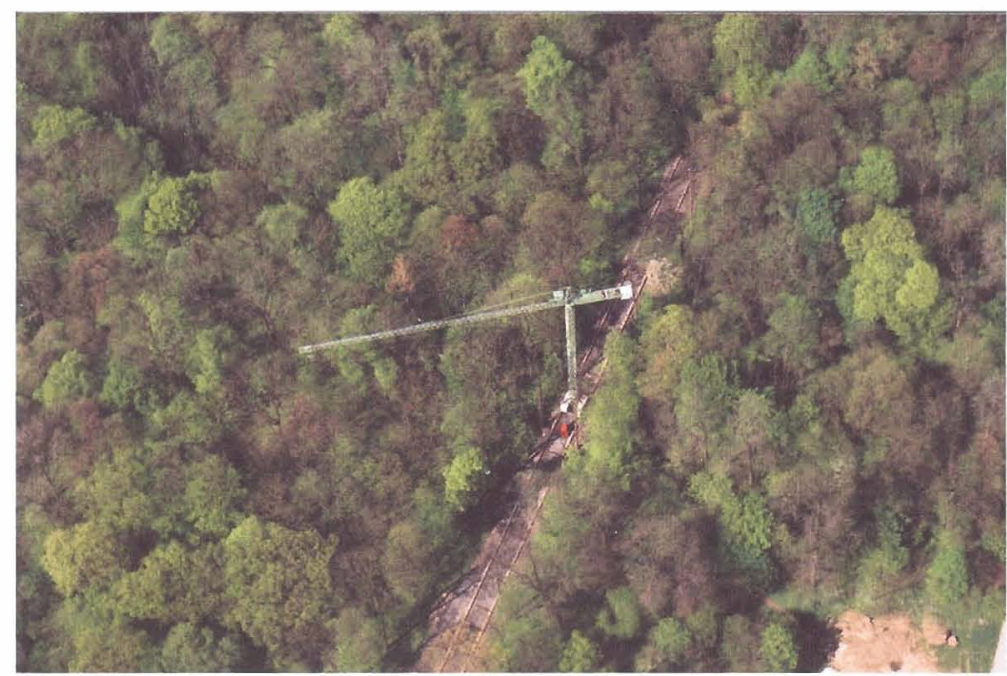

Figure 1 Aerial photo of crane and rail track. Courtesy UTZ Leipzig-Halle AG.

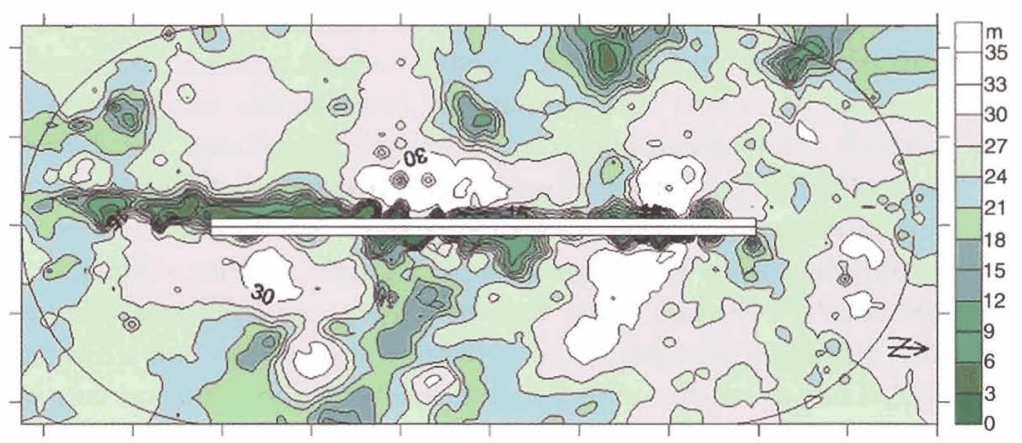

Figure 2 Map of the canopy topography in the crane plot. Note: The ellipsoid represents the area reached by the gondola $(210 \mathrm{~m} \times 90 \mathrm{~m}$ ). The central depression (dark green and grey bar) reflects the rail track position, the other ones natural canopy gaps. 


\section{Stand Structure}

The forest stand shows a variety of different stem classes and heights, and thus resembles a natural forest with a well-structured outer canopy, including natural tree fall gaps. The canopy topography has been measured in detail (see Figure 2), and some first vertical light (PAR) measurements allowed us to identify three distinct zones in the canopy similar to those found in an old Douglas-fir/western hemlock stand by Parker (1997). A very dark zone at the forest floor is followed by a zone of highly varying light conditions and leads to an upper zone of bright light.

\section{Phenology}

A detailed study of the trioecious tree species Fraxinus excelsior $L$. revealed a striking spatial and temporal variability in generative and vegetative phenology in the distribution of its three flower types as well as in its leaf and branching pattern and morphology. The investigation of this focal species will be continued and will include more detailed studies on reproductive ecology and population genetics.

\section{Herbivory}

Two preliminary studies aimed to assess the degree of stand-level herbivory revealed very low values $(<1$ percent) in the range of coniferous forests. The data showed inter-specific differences (trends) in herbivory with high intra-specific variation. Some species also showed differences (trends) in herbivory at different heights (e.g., upper canopy vs. lower canopy).

\section{Arthropods}

Arthropods were collected by flight interception traps, barber traps, emergence traps, and trunk and branch traps. Preliminary results indicate a different fauna at the ground vs. the canopy, especially in the groups Carabidae, Lepidoptera, and Araneae. Arthropods mostly found in the canopy are often considered to be rare and threatened species in Germany. The majority of the collected animals still await identification.

\section{Cryptograms}

Lichens, which are very species-poor in Leipzig due to its dry climate and formerly bad air quality, are now colonizing the canopy, including some very rare species. Fungi are quite diverse $(>76$ spp.), and some species show tendencies to settle in distinct canopy zones. Also, 15 species of slime molds (Myxomycota) were encountered in the canopy in a preliminary survey.

\section{Bats}

Preliminary studies of the flight activities of bats in the canopy revealed very complex adaptations to the habitat structure, with some tendency to use the upper canopy zone more frequently. Some completely new discoveries were also made simply due to the fact that formerly, almost no one reached this canopy habitat. The most notable finding has been the presence of the greenback frog (Hyla arborea L.) in the upper canopy (Schmidt et al. 2003). 


\section{THE LEIPZIG CANOPY CRANE PROJECT: BIODIVERSITY, ECOLOGY, AND FUNCTION IN A TEMPERATE DECIDUOUS FOREST-cont'd}

\section{References}

Morawetz, W. and Horchler, P. (2002). The Leipzig Canopy Crane Project. In "The Global Canopy

Handbook. Techniques of Access and Study in the Forest Roof" (A.W. Mitchell, K. Secoy, and T. Jackson, Eds.), pp. 54-57. Global Canopy Programme, Oxford.

Parker, G.G. (1997). Canopy structure and light environment of an old-growth Douglas-fir/Western Hemlock forest. Northwest Science 71, 261-270.

Schmidt, C., Unterseher, M., and Grosse, W. R. (2003). Hoch hinaus - Sitzwarten beim Laubfrosch (Hyla arborea L.) in Baumkronen des Lcipziger Auwalds. Elaphe 11, Heft 2. S. 43-45.

Schowalter et al. 1991) and subsequent nutrient export (Swank et al. 1981). Interactions among canopy herbivores, soil mesofauna, and the processes of decomposition, however, remain to be quantified (Schowalter et al. 1986; Risley and Crossley 1993; Reynolds and Hunter 2001; Reynolds et al. 2003).

Thus, herbivory takes two major routes in influencing decomposition on the forest floor. First, solid materials drop to the floor during or following herbivory. Specifically, insect frass, greenfall, and prematurely abscised leaves represent major inputs to the soil community resulting from herbivory (Lovett and Ruesink 1995; Schowalter and Sabin 1991; Schowalter et al. 1991). Second, rainfall collects some products of herbivory and introduces those products to the soil in liquid form. This canopy throughfall represents the combined effects of dissolved insect frass and modified leachates from damaged foliage. Both pathways result in the input of carbon, nitrogen, and phosphorus to the decomposer community.

\section{Forests as Regulators of Herbivory}

Not only do herbivores affect plant communities, but the forests themselves influence herbivores through complex feedback mechanisms. Leaf emergence can have a "bottom-up" trophic effect on an ccosystcm. Leaf abscission and leaf fall, too, can affect insect herbivores. Soil biologists have long recognized the influence of plant communities on ccosystem proccsses, but only recently have forest ecologists attempted to quantify those linkages (Wardle 2002).

Generalities about differences in leaf phenological patterns between temperate and tropical forests must first acknowledge the broad variation in a single latitude (Lowman 1995a). Nonetheless, most broad-leaved trees in temperate forests produce new foliage in spring and drop old foliage in fall. Foliage is largely abscnt for the rest of the year, as are insect folivores; and the availability of young expanding leaves shows a marked peak in the spring.

Trees exhibit significant variation in both budburst date and the timing of lcaf abscission (Hunter 1992). Variation in the phenology of leaf flush and leaf loss occurs at several spatial scales with differences among forest types, among tree species, among individual trees within the same population, and cven among canopy layers within individual plants (Lowman 1992, 1995a; Heatwole et al. 1997). The origins of such phenological variation (genetic, ontogenetic, and/or environmental) and the cological conscquences for the trees and the communities within which they live remain matters for debate (Phillipson and Thompson 1983; Hunter 1992). Phenological variation in leaf flush and leaf fall, however, clearly provides the kind of spatial and temporal heterogeneity in resource availability that determines the form of interactions among organisms 
in natural communities (reviewed in Dajoz 2000). For example, several authors have suggested that differences among individual trees in their budburst dates are related to insect herbivore performance and population densities and suffer greater levels of defoliation than those that burst bud late (Hunter 1990, 1992). Spatial variation in budburst phenology determines herbivore load and, consequently, influences canopy-wide defoliation levels and the distribution of frassfall and greenfall to the forcst floor.

Though general agreement among aquatic ecologists exists for the widespread significance of trophic cascades (the effects of predators on the biomass of organisms at least two links away), the issue of whether cascades are similarly important in terrestrial communities is debatable (Pace et al. 1999; Holt 2000; Polis et al. 2000; Power 2000; Wardle 2002; Prcisser 2003). In at least one system, variation in the timing of leaf expansion for forest trees is thought to have a cascading effect through the trophic system from plants through insect herbivores to avian predators (Hunter and Price 1992). In this case, the budburst phenology of Quercus robur varies spatially and temporally and drives the population dynamics of two spring lepidopterans. These herbivorous insects usually maintain populations below competitive levels; however, when competition does occur, the sensitivity of one species to budburst phenology reverses its competitive advantagc it would have otherwise over the second species. Avian predators (e.g., Parus spp.) track the yearly changes in defoliator populations, exhibiting large clutches in years of high lepidopteran density.

Leaf abscission is another critical event in the dynamics of a forest. Spatial and temporal variation in the timing of leaf fall influences herbivore densities and may determine patterns of foraging by herbivores within and among trees. Leaf fall also represents one major pulse of resource input into the decomposer community on the forest floor. Thus, spatial and temporal variations in leaf abscission are reflected in variation in the activities of decomposers.

In European temperate forests, dominated by oaks, the temporal distributions of herbivores closely track leaf expansion. Feeny's (1970) work on the English oak, Quercus robur, demonstrated a spring-skewed species richness of oak herbivores. A sccond smaller peak in late summer/fall includes species that respond to a second flush of oak foliage resulting from spring defoliation. Yet more than 95 percent of the total defoliation on Q. robur occurs between budburst in April and the beginning of June, presumably because of seasonal declines in foliage quality (Feeny 1970; MeNcill and Southwood 1978). As leaves age, they generally become lower in total nitrogen and water (Mattson 1980) and are often higher in fiber, lignin, and polyphenols than are younger leaves (Cates 1980). Inevitably, cxamples occur of insect-herbivores that prefer mature foliage (Cates 1980), but defoliation events are most usually associated with young leaves (Lowman 1992; Schowalter 2000). In rainforests, young lcaves are more extensively grazed by insect-herbivores than are old leaves (Coley 1983; Lowman 1984, 1992; Coley and Aide 1991). In most deciduous forests in the eastern United States, folivory also is skewed toward newly emerged leaves (Rcichle et al. 1973).

The tropics are not aseasonal. Most plants in the tropics produce new leaves periodically rather than continuously, and some synchrony occurs among different plant species, suggesting adaptive responses to biotic or abiotic variables (Van Schaik et al. 1993). Nonetheless, leaf emergence in tropical wet forests does not exhibit the same pronounced seasonal peak as in temperate forests. Much more inter-specific variability in leaf flush and leaf fall exists in tropical wet forests than in temperate forests. For example, in a French Guianan forest, each deciduous tree species appears to cxhibit its own endogenous periodicity for shedding leaves (Loubry 1994). A 12-year study of flowering for 173 tree species at La Selva Biological Station in Costa Rica concluded that tree phenology was highly diverse, irregular, and complex (Newstrom et al. 1994). The authors also concluded that many tropical tree species show greater variation in phenology than do temperate species. Data on fruit fall from the Luquillo Expcrimental Forest in Puerto Rico suggest that, despite strong seasonal pulses in fruit production, a stand in some part 
of the forest is always in peak fruit production (Lugo and Frangi 1993). Tree species in Australian rainforest show a diversity of leaf flush phenologies from scasonal to continuous (Lowman 1992). Tropical dry forests show more seasonal patterns of leaf flush than do tropical wet forests, and the production of new foliage appears to peak toward the end of the dry scason, perhaps avoiding the peak emergence of insect folivores that begins with the rains (Aide 1992). Even in tropical dry forest, however, more inter-spccific variability in phenology is apparent than in tomperate forests.

The responses of insect herbivores to leaf emergence are arguably even more pronounced in tropical wet forests than they are in temperate forests (Dajoz 2000). Most herbivory on tropical forest leaves occurs very early during expansion and may be even more skewed toward young leaves than defoliation in temperate forests (Reichle et al. 1973). The accumulation of herbivory throughout the forest should still occur morc cvenly through the year in wet tropical forcsts than in temperate forests (see Schowalter 2000). Despite clear pulses of leaf expansion in tropical wet forests, new leaves are still produced over cxtended periods. Data presented by Coley and Aide (1991) suggest, for example, that during eight months in Oak Ridge, Tennessee, no new leaves were produced on trees compared with only two months without new leaf production at La Selva, Costa Rica, and four months in Semego, Sarawak. Although both tropical wet forests and temperate forests exhibit seasonal peaks in leaf expansion, those peaks are broader in the tropics.

\section{Methodologies to Assess Herbivory: Are They Accurate?}

The turnover of photosynthetic tissues has direct impact on the growth and maintenance of the trees, vines, epiphytes, and herbaceous layers of forests (sce Figure 18-6). The production of green tissuc is also indirectly responsible for the maintenance of all animal life in the canopy. The ability of biologists to measure foliage and to predict photosynthetic activity has become an important topic for forcst conservation. Obviously, it is important to make accurate measurements of

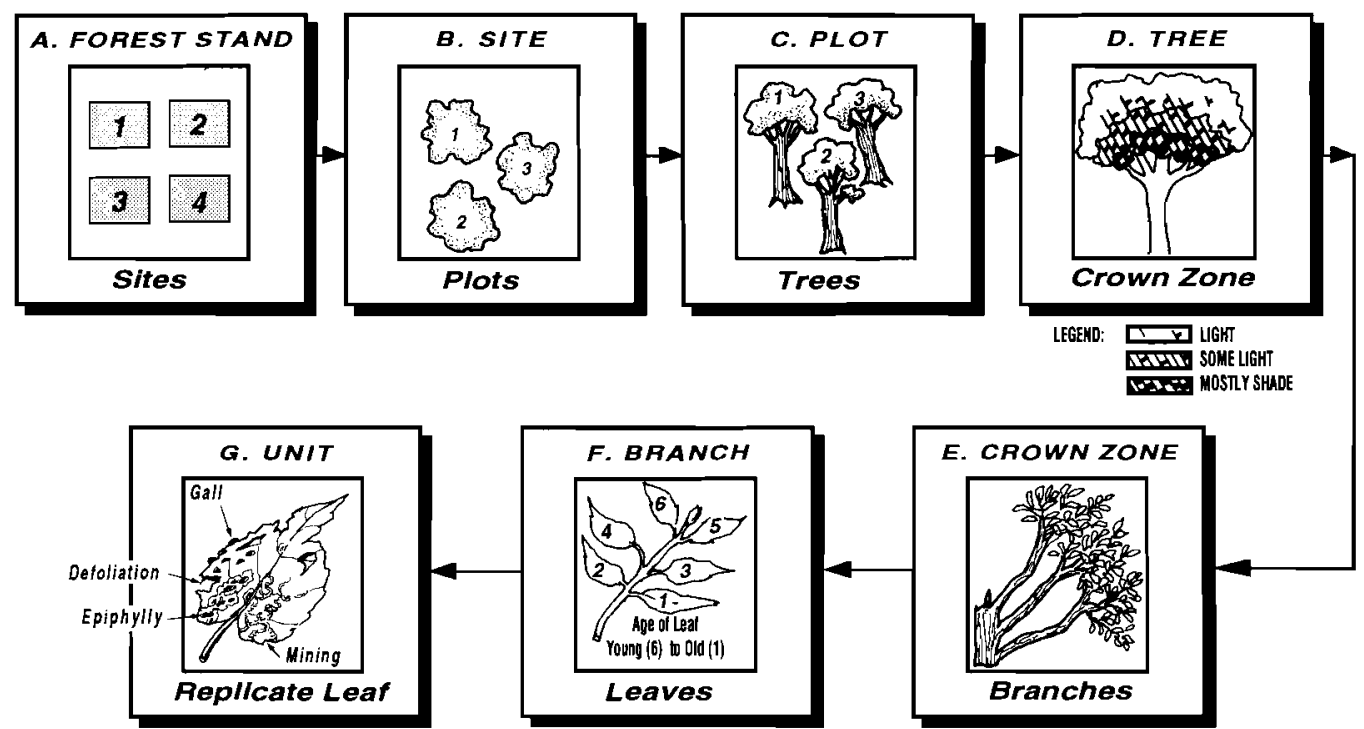

Figure 18-6 Experimental design for canopy foliage studies, illustrating the replication recommended at the spatial scalcs of forest stand, site, plot, tree, crown zone, branch, and leaf unit (from Lowman 1995b; used with permission). 
both the production of foliage in a forest and of the removal of leaf material by herbivores to assess forest productivity.

'The methods and spatial scales used to determine herbivory have direct consequences on our understanding of herbivore dynamics (see Figure 18-7). It should be noted forthwith that the source of variability in defoliation levels within and between forest sites might be a residual effect of different methodologies employed by researchers. Southwood (1961) cxamined insect specics in tree canopics in Great Britain. For several species of temperate deciduous trees, he found that more diversity was associated with trees that had becn established over a long period of time as compared to species introduced more recently. His insecticidal knockdown procedure has since been altered to include misting (Kitching et al. 1993), fogging (Erwin 1982), and restricted canopy fogging (Basset 1992) as more biologists become curious about the variety and numbers of insects in tree canopies. Similar to the artifacts of sampling for foliage consumption measurements, the

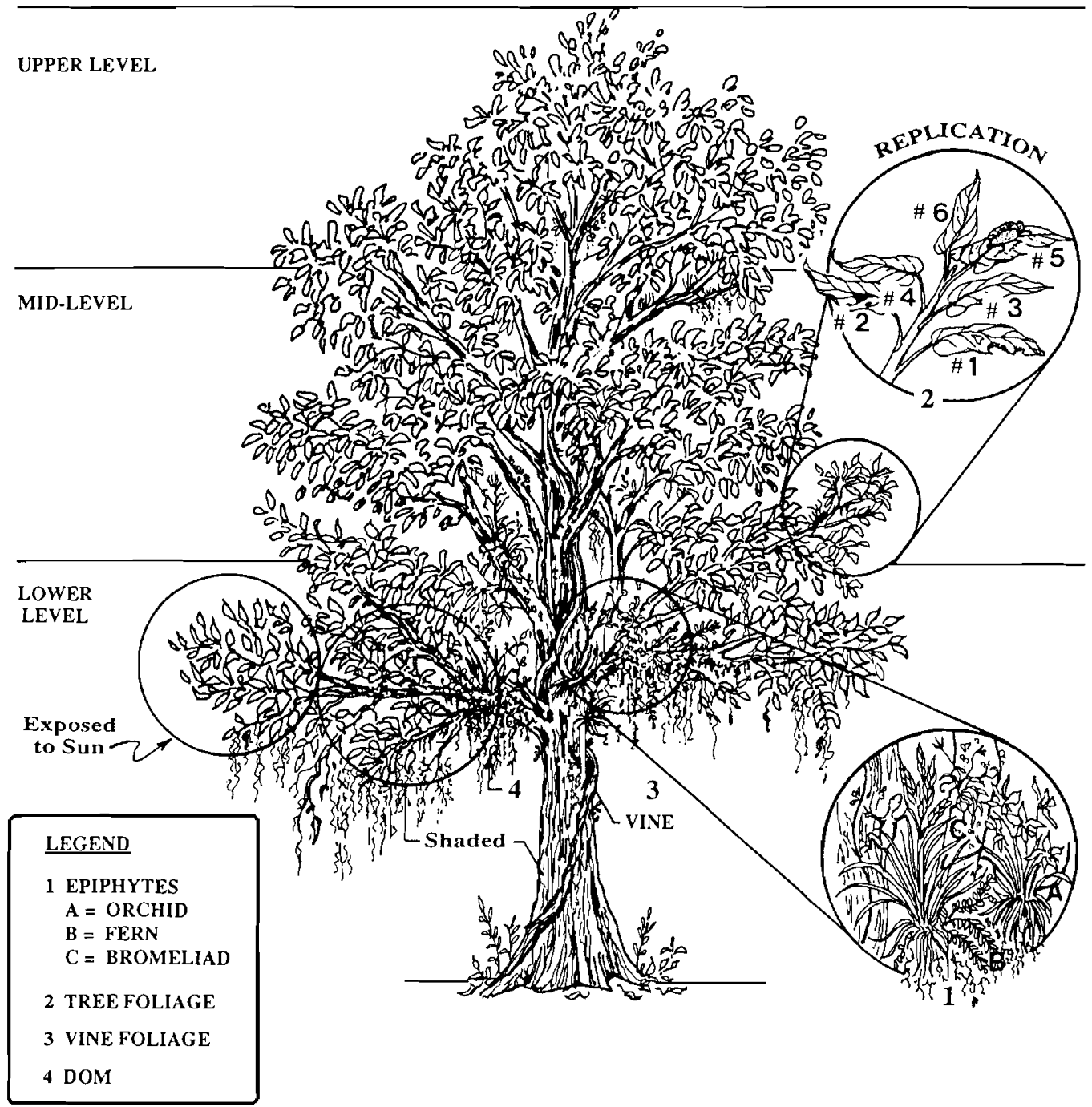

Figure 18-7 Schematic diagram of the components of a forest canopy to sample, including epiphytes (c.g., orchids, bromeliads, ferns), tree foliage, vines, and DOM (dead organic matter) (from Lowman 1995b; used with permission). 
variability in methodologies to assess the diversity of insects in trees also leads to discrepancies in our estimates of herbivorous insects.

As biologists became interested in defoliation historically, a plethora of literature on herbivory emerged, much of which utilized different, but not entirely compatible, methodologies. For example, the techniques used to measure foliage losses included visual estimates (Wint 1983), graph paper tracings (Lowman 1984), templates in the field (Coley 1983), and leaf area meters (Lowman 1984). Similarly, the sampling designs varied dramatically, including collected leaves in litter traps (Odum and Ruiz-Reyes 1970), undefined leaf selection (Bray 1964), marked leaves in the understory (Coley 1983) and upperstory (Lowman 1985), marked leaves along a vertical transect (Lowman 1992), and collected frass (Ohmart et al. 1983). Obviously, such sampling designs may be adequate for a particular hypothesis, but they are not conducive to inter-site comparisons (Lowman 1987). In some cases, literature reviews have misquoted herbivory levels, perhaps because it is so difficult to interpret the various methodologies employed in different studies (Landsberg and Ohmart 1989).

Comparison of discrete versus long-term measurement techniques in rainforest canopies revealed discrepancies up to fivefold, with long-term studies producing significantly higher measurements than short-term ones. For example, estimates of herbivory levels in neotropical saplings were three times higher than in previous studies that used discrete harvested leaves (21 percent in Coley 1983 versus 7 percent in Odum and Ruiz-Reyes 1970). Similarly, long-term measurements of coral cay shrubs produced estimates of 21 percent missing area (Heatwole et al. 1981) compared to levels of 2 to 3 percent measured by discrete sampling (Lowman 1984). Grazing in some plant communities may be higher than previously recorded from discrete measurements of missing leaf area, resulting in an under-estimation of the impact of herbivory. Temporal variability in levels of herbivory further complicates our ability to monitor this canopy process.

In addition to the potential areas from methods that do not account for heterogeneity of foliage throughout the canopy, other methods must be used with caution. Daily rates of defoliation are useful but can be misleading if measured only over short durations, as they will not include seasonal differences. Ranking and other grazing categories are useful for rapid assessment, but such information is not transformable into statistical analyses. Further, the assumption that the absence of leaf petioles indicates 100 percent defoliation may be misleading because physical factors are also responsible for loss of leaf blades. The extent to which methods may alter results remains a critical issue in the literature on herbivory.

\section{Conclusion: The Little Things vs. the Big Things that Sustain Forest Health}

Aldo Leopold, an eloquent American pioneer for conservation, wrote in his now-famous $A$ Sand County Almanac (1949):

Land, then, is not merely soil; it is a fountain of energy flowing through a circuit of soils, plants, and animals. Food chains are the living channels that conduct energy upward; death and decay return it to the soil. The circuit is not closed; some energy is dissipated in decay, some is added by absorption from the air, some is stored in soils, peats, and long-lived forests; but it is a sustained circuit, like a slowly augmented revolving fund of life.

That sustained circuit is the life-blood of forest systems around the world.

In 1988, one year after E.O. Wilson inaugurated the invertebrate exhibit at the National Zoo, an article by John Terborgh appeared in Conservation Biology that seemingly disputed the previous argument by Wilson. Terborgh, then professor in Princeton University's biology department, reasoned that hunting out top carnivores and herbivores, while fragmenting the landscape into patches too small to maintain the whole interlocking ecological system, would erode biodiversity at all levels. 
"In the end, this would work to the detriment of many of Professor Wilson's 'little things.' The essential point is that the big things are important, too; what is worrisome in these changing times is that they are so much more vulnerable" (Terborgh 1988). The "little things" may run the world, but the "big things" provide a stabilizing function in regional ecosystems via their functional longevity (Redford 1992). Yet, according to Terborgh, the "big things" are more susceptible to environmental perturbations and human exploitation than are fast-breeding, but short-lived, arthropods and worms. Thus, both the "little things" and the "big things" are indispensable to sustain the health and integrity of forest systems.

Terborgh's assertion seems almost disingenuous, or at least unconvincing, in the light of the sheer diversity, distribution, and abundance of arthropods. If there are indeed 30 million species of insects and just about 4,600 species of mammals, then beetles, bugs, ants, and flies far outweigh peccaries, pacas, and agoutis in both their biomass and their ecological significance to global food webs. If the "big things" were to disappear overnight, inevitably there would be short-term disruption of global ecosystems; however, after a geological flash, another kind of stability would probably settle across the planet. One need only remember the readjustment of woodland ecosystems after the rapid, poignant demise of the passenger pigeon, arguably a one-time keystone species for the forests of eastern North America. (e.g., see Wilcove 1989; Shaw 1995). On the other hand, if the "little things" were to vanish, one suspects that the ecological link between forest canopies and soils might be disrupted and, consequently, that both the health and integrity of the energy circuit be diminished. This chapter argues that insect herbivores in forest canopies and soil mesofauna are some of Leopold's little "cogs and wheels" that sustain this complex system.

\section{Acknowledgments}

The authors wish to thank the National Science Foundation (DEB-9815133), the Global Canopy Programme, and the Triad Foundation (Ithaca, New York) for their generous support for field research apropos to this chapter.

\section{Appendix: Numbers of Estimated Host-Specific Beetle Species per Trophic Group on Luehea semannii (from Erwin 1983)}

\begin{tabular}{lccc} 
Trophic Group & Number of Species & Percent Host-Specific & Number Host-Specific \\
\hline Herbivores & 682 & $20 \%$ & 136 \\
Predators & 296 & $5 \%$ & 15 \\
Fungivores & 69 & $10 \%$ & 7 \\
Scavengers & 96 & $5 \%$ & 5 \\
Total & $1200+$ & & 163 \\
\hline
\end{tabular}

Erwin's Estimation of 30 Million Species:

1. Luehea $=163 / 1200=13.6$ percent host-specific species

2. Average Tropical Forest $=70$ trees $/$ ha

3. $163 \times 70=11,410$ host-specific beetle species $/$ ha

4. 1200 total beetle species $=163$ host-specific +1037 transient species for one Luehea

5. 11,410 host-specific $/$ ha +1037 transients $=12,447$ beetle species $/$ ha

6. Beetles $=40$ percent all insect species, 31,118 insect species/ha in canopy of tropical forest 
7. Canopy species twice as rich as species on forest floor, add one-third more species to canopy figure: $31,118+10,373=41,491$ insect species $/$ ha of tropical forest

8. 41,491 insect species $/ 70$ trees $/$ ha $=593$ insect species $/$ tree

9. 593 insect species $/$ tree $\times 50,000$ species of tropical trees $=$ approx. 30 million species

Arcas of Uncertainty for Erwin's Calculations (see André et al. 1994):

1. What fraction of the bcctle fauna on a given tree species is effectively specializcd to it?

2. Do bectle species constitute the same fraction of insect fauna in the tropics that they do in better-studied temperatc rcgions?

3. For each insect species in the canopy, how many other species are found elsewhere in or around a trce?

4. How do we scale up from the number of insect spccics associated with a given tree in a given place to a global total?

5. What is the relationship between insect fauna and trce phenology?

\section{References}

Aide, T.M. (1992). Dry season leaf production: an uscape from herbivory. Biotropica 24, 532-537.

André, II.M., Noti, M-I., and Lebrun, P. (1994). The soil fauna: the other last biotic frontier. Biodiversity and Conservation 3, 45-56.

Barbosa, P. and Schultz, J.C. (1987). "Insect Outbreaks." Aeademie Press, Orlando, Florida.

Basset, Y. (1991). The spatial distribution of herbivory, mines and galls within an Australian rain forest tree. Biotropica 23, 271-281.

Basset, Y. (1992). Host specificity of arborcal and frec-living insect herbivores in rain forests. Biol. J. Linn. Soc. 47, 115-133.

Basset, Y., Nberlene, P.II., and Delvare, G. (1991). Abondance, diversite et stratification verticale de l'entomofaune d'une foret tropicale humide Africainc. In "Biologie d'Une Canopée de Forêt Équatoriale II" (F. IIallé and O. Pascal, Eds.), pp. 45-52. Opération Canopée, Lyons, France.

Basset, Y., Novotny, V., Miller, S.E., and Kitehing, R.L. (2003). "Arthropods of Tropical Forests: SpatioTemporal Dynamies and Resouree Use in the Canopy." Cambridge University Press, Cambridge, UK.

Bray, J.R. (1964). Primary consumption in three forest eanopies. Ecology 45(1), 165-167.

Bray, J.R. and E. Gorham. (1964). Litter production in forests of the world. Adv. Ecol. Res. 2, 101-157.

Cates, R.G. (1980). Feeding patterns of monophagous, oligophagous, and polyphagous insect herbivores: The effect of resource abundance and plant ehemistry. Oecologia 46, 22-31.

Clark, L. R. (1962). The general biology of Cardiaspina albitextura (Psyllidac) and its abundance in relation to weather and parasitism. Australian. Journal of Zoology 10, 537-586.

Colev, P.D. (1983). Herbivory and defensive characteristics of tree species in a lowland tropical forest. Ecological Monographs 53, 209-233.

Colev, P.D. and T.M. Aide (1991). Comparison of herbivory and plant defenses in temperate and tropical broad-leaved forests. In "Plant-Animal Interactions: Evolutionary Ecology in Tropical and Temperate Regions" (P.W. Priec, T.M. Lewinsohn, G.W. Fernandes, and W.W. Benson, Eds.), pp. 25-49. John Wiley and Sons, Inc., New York.

Colinvaux, Paul. (1997). Ancient sediments show rain forest covered Amazon Basin in last ice age. Smithsonian Institution Research Report 87.

Dajo\%, Roger. (2000). "Inseets and Forests: The Role and Diversity of Inseets in the Forest Environment." Lavoisier, Paris.

De Mazaneourt, C., Loreau, M., and Abbadie, L. (1998). Grazing optimatization and nutrient eyeling: When do herbivores enhance plant production? Ecology 79, 2242-2252.

De Mazaneourt, C.L. and Loreau, M. (200)(0). Effect of herbivory and plant species replacement on primary production. The American Nuturalist $\mathbf{1 5 5}(6), 735-754$

DeVries, P.J. (1987). "The Butterflies of Costa Rica and Their Natural History: Papilionidae, Pieridae, Nymphalidae." Prinecton University Press, Princeton, New Jersey.

Diamond, J. (1986). Overview: Laboratory expcriments, field experiments and natural experiments. In "Community Ecology" (J. Diamond and T.J. Casce, Eds.), pp. 3-22. Ilarper and Row, New York. 
Erwin, T. (1982). Tropical forests: Their richness in Coleoptera and other arthropod species. The Coleopterists Bulletin 36(1), 74-75.

Erwin, T. (1983). Tropical forest canopies: The last biotic frontier. Bulletin of the Entomological Society of America 29, 14-19.

Fecny, P. (1970). Seasonal changes in oak leaf tannins and nutrients as a cause of spring feeding by winter moth caterpillars. Ecology 51(4), 565-581.

Fox, L.R. and Morrow, P.A. (1983). Estimates of damage by inseet grazing on Eucalyptus trees. Australian Journal of Ecology 8. 139-147.

Gentry, A.H. (Ed.) (1990). "Four Neotropical Forests." Yale University Press, New Ilaven, CT.

IIeatwole, II., Done, T., and Cameron, E. (1981). "Community Ecology of a Coral Cay, a Study of One Tree Island, Great Barrier Reef." Dr. W. Junk Publications, The Hague, The Netherlands.

Heatwole, H., Lowman, M.D., Donovan, C., and MeCoy, M. (1997). Phenology of leaf-flushing and macroarthropod abundanecs in eanopies of Eucalyptus saplings. Selbyana 18(2), 200-214.

Ilölldobler, B. and Wilson, E.O. (1990). "The Ants." Belknap Press of Harvard University Press, Cambridge, Massachusetts.

Holt, R.D. (2000). Trophic cascades in terrestrial ecosystems. Reflections on Polis et al. Trends in Ecology and Evolution 15(11), 444-445.

Ilulfaker and Gutierrez. (1999). "Ecological Entomology." John Wiley and Sons, New York.

Hunter, M.D. (1990). Differential susceptibility to variable plant phenology and its roles in competition between two insect herbivores on oak. Ecological Entomology 15, 401-408.

Hunter, M.D. (1992). A variable insect-plant interaction: The relationship between tree budburst phenology and population levels of insect herbivores among trees. Ecological Entomology 17, 91-95.

Hunter, M.D. and Price, P.W. (1992). Playing chutes and ladders: Ileterogeneity and the relative roles of bottom-up and top-down forces in natural communities. Ecology 73, 724-732.

Janzen, D.H. (1983). "Costa Rican Natural Ilistory." University of Chicago Press, Chicago.

Kitchell, J.F., O'Neill, R.V., Webb, D., Gallep, G.A., Bartell, S.M., Koonce, J.F., and Ausmus, B.S. (1979). Consumer regulation of nutrient eycling. Bioscience 29, 28-34.

Kitching, R.L., Bergelsohn, .J.M., Lowman, M.D., MacIntyre, S., and Carruthers, G. (1993). The biodiversity of arthropods from Australian rain forest canopies: General introduction, methods, sites and ordinal results. Australian Journal of Ecology 18, 181-191.

Koike, F. and Nagamitsu, Teruyoshi. (2003). Canopy foliage structure and flight density of butterfies and birds in Sarawak. In "Arthropods of Tropical Forests: Spation-Temporal Dynamies and Resource Use in the Canopy" (Y. Basset, N. Novotny, S. E. Miller, and R. L. Kitehing, Eds.), pp. 86-91. Cambridge University Press, Cambridge, United Kingdom.

Kricher, J. (1997). "A Neotropical Companion: An Introduction to the Animals, Plants, and Ecosystems of the New World Tropies." Princeton University Press, Princeton, New Jersey.

Landsberg, J. and Ohmart, C.P. (1989). Levels of defoliation in forests: Patterns and concepts. Trends in Ecology and Evolution 4, 96-100.

Lawton, J. H. and Schröder, D. (1997). Effects of plant type, size of geographic range, and taxonomic isolation on number of insect species associated with British plants. Nature 265, 137-140.

Leopold, A. (1949/1966). "A Sand County Almanac." Oxford University Press, New York.

Lerdau, M. (1996). Insects and ecosystem function. Trends in Ecology and Evolution 11, 151.

Linsenmair, K.E., Davis, A.J., Fiala, B., and Speight, M.R. (2001). "Tropical Forest Canopies: Ecology and Management." Kluwer Academic Publishers, Dordrecht, The Netherlands.

Loreau, M. (1995). Consumers as maximizers of matter and energy flow in ecosystems. The American Naturalist 145, 22-42.

Loubry, D. (1994). Phenology of deciduous trees in a French Guianan forest (5 degrees latitude north): Case of a determinism with endogenous and exogenous component. Canadian Journal of Botany 72, 1843-1857.

Lovett, G.M. and Ruesink, .E. (1995). Carbon and nitrogen mineralization from decomposing Gypsy moth frass. Oecologia 104, 133-138.

Lowman, M.D. (1982). "Leaf Growth Dynamics and Iferbivory in Australian Rain Forest Canopies." Ph.D. Thesis, University of Sydney, Sydney, Australia.

Lowman, M.D. (1984). An assessment of techniques for measuring herbivory: Is rain forest defoliation more intense than we thought? Biotropica 16(4), 264-268.

Lowman, M.Đ. (1985). Temporal and spatial variability in inseet grazing of the canopies of five Australian rain forest tree species. Australian Journal of Ecology 10, 7-24.

Lowman, M.D. (1987). Insect herbivory in Australian rain forests: is it higher than in the neotropics? Proceedings of the Ecological Society of Australia 14, 109-119. 
Jowman, M.D. (1988). Litterfall and leaf decay in three Australian rain forest formations. Journal of Ecology 76, $451-465$.

Lowman, M.D. (1992). Leaf growth dynamics and herbivory in five species of Australian rain forest canopy trees. Journal of Ecology 80, 433-447.

Lowman, M.D. (1993). Forest canopy research: Old World, New World comparisons. Selbyana 14, 1-2.

Lowman, M.D. (1995a). Ilerbivory in Australian forests: a comparison of dry selerophyll and rain forest canopies. Proceedings of the Linnaean Society 115, 77-87.

Lowman, M.D. (1995b). Herbivory as a canopy process in rain forest trees. In "Forest Canopies"

(M.D. Lowman and N.M. Nadkarni, Eds.), pp. 431-455. Academic Press, San Diego.

Jowman, M.D. and Heatwole, H. (1992). Spatial and temporal variability in defoliation of Australian eucalypts. Ecology 73, 129-142.

Lowman, M.D. and Moffett, M. (1993). The ecology of tropical rain forest canopies. Trends in Ecology and Evolution 8(3), 104-107.

Lowman, M.D., Moffett, M., and Rinker, H.B. (1993). A new technique for taxonomic and ecological sampling in rain forest canopies. Selbyana 14, 75-79.

Lowman, M.D. and Morrow, P. (1998). Insects and their environment: plants. In "The Science of Entomology" (W.S. Romoser and J.G. Stoffolano, Eds.), pp. 290-316. WCB MeGraw-Hill, Boston, Massachusetts.

Lowman, M.D. and Nadkarni, N.M. (1995). "Forest Canopies." Academic Press, San Diego.

Lowman, M.D., Foster, R., Wittman, P., and Rinker, H.B. (1998). Herbivory and insect loads on epiphytes, vines, and host trees in the rain forest eanopy of French Guinana. In "Biologie d'Une Canopéc de Forêt Équatoriale III" (Francis Hallé, Ed.), pp. 116-128. Pro-Natura International and Opération Canopée, Paris, France.

Lowman, M.D. (1999). "Life in the Tree tops." Yale University Press, New Haven, Conn.

Lugo, A.E. and Frangi, J.L. (1993). Fruit fall in the Luquillo experimental forest, Puerto Rico. Biotropica 25, $73-84$.

MacArthur, R.H. (1969). Patterns of communities in the tropies. Biological Journal of the Linnaean Society 1, $19-30$.

MacArthur, R.II. (1972). "Geographic Ecology: Patterns in the Distribution of Species." Princeton University Press, Princeton, New Jersey.

Marquis, R. (1991). Ilerbivore fauna of Piper (Piperaceae) in a Costa Rican wet forest: Diversity, specificity and impact. In "Plant-Animal Interactions, Evolutionary Ecology in Tropical and Temperate Regions" (P. Price, T.M. Lewinsohn, G.W. Fernandes, and W.W. Benson, Eds.), pp. 179-208. Wiley, New York.

Mattson, W.J. (1980). Herbivory in relation to plant nitrogen content. Annual Review of Ecologv and Systematics 11, 119-161.

Mattson, W.J. and Addy, N.D. (1975). Phytophagous inseets as regulators of forest primary production. Science 190, 515-522.

Mawdsley, N.A. and Stork, N.E. (1997). Host-speeificity and the effective specialization of tropical canopy beetles. In "Canopy Arthropods" (N.E. Stork, J. Adis, and R.K. Didham, Eds.), pp. 104-130. Chapman and Hall, London, UK.

MeInnes, P.F., Naiman, R.J., Pastor, J., and Cohen, Y. (1992). Effects of moose browsing on vegetation and litter of the boreal forest, Isle Royale, Michigan, USA. Ecology 73, 2059-2075.

MeNeill, S. and Southwood, T.R.E. (1978). The role of nitrogen in the development of insect/plant relationships. In "Biochemical Aspects of Plant and Animal Coevolution: Proceedings of the Phytochemical Society Symposium, Reading, April 1977” (J.B. Harbourne et al., Ed.), pp. 77-98. Academic Press, New York.

Molvar, E.M., Boyer, R.T., and Vanballengerghe, V. (1993). Moose herbivory, browse quality, and nutrient cycling in an Alaskan treeline community. Oecologia 94, 472-479.

Montgomery, G.G. (1978). "The Ecology of Arboreal Folivores." Smithsonian Institution, Washington, DC.

Morrow, P.A. and Fox, L.R. (1980). Effects of variation in Eucalyptus essential oil on insect growth and grazing damage. Oecologia $45,209-219$.

Newstron, L.E., Frankie, G.W., and Baker, H.G. (1994). A new classification for plant phenology based on flowering patterns in lowland tropical rain forest trees at La Selva, Costa Rica. Biotropica 26(2), 141-159.

Novotny, V., Basset Y., and Kitching, R.L. (2003). Herbivore assemblages and their food resources. In "Arthropods of Tropical Forests: Spatio-Temporal Dynamies and Resource Use in the Canopy" (Y. Basset, V. Novotny, S.E. Miller, and R.L. Kitching, Eds.), pp. 40-53. Cambridge University Press, Cambridge, United Kingdom.

Odum, H.T. and Ruiz-Reves, J. (1970). Holes in leaves and the grazing control mechanism. In "A Tropical Rain Forest" (H.T. Odum and R.F. Pigeon, Eds.), pp. I-69-I-80. U.S. Atomic Energy Commission, Oak Ridge, Tennessee.

Ohmart, C.P, Stewart, L.G., and Thomas, J.L. (1983). Phytophagous insect communities in the eanopies of three Eucalyprus forest types in south-castern Australia. Australian Journal of Ecology 8, 395-403. 
Pace, M.L., Cole, J.J., Carpenter, S.R., and Kitchell, J.F. (2000). Trophic cascades revealed in diverse ecosystems. Trends in Ecology and Evolution 14(12), 483-488.

Pastor, J. and Y. Cohen. (1997). Herbivores, the functional diversity of plant speeies, and the cycling of nutrients in boreal ecosystems. Theoretical Population Biology 51, 165-179.

Pastor, J., Dewey, B., Naiman, R.J., MeInnes, P.F., and Cohen, Y. (1993). Moose browsing and soil fertility in the boreal forests of Isle Royale National Park. Ecology 74, 467-480.

Phillipson, J. and Thompson, D.J. (1983). Phenology and intensity of phytophage attack on Fagus sylvatica in Wytham Woods, Oxford. Ecological Entomology \&, 315-330.

Pitelka, F.A. (1964). The nutrient-recovery hypothesis for arctic microtine cycles. I. Introduction. In "Grazing in Terrestrial and Marine Environments" (D.J. Crisp, Ed.), pp. 55-56. Blackwell, Oxford, UK.

Polis, G.A., Sears, A.L.W., Huxel, G.R., Strong, D.R., and Maron, J. (2000). When is a trophic cascade a trophic cascade? Trends in Ecology and Evolution 15(11), 473-475.

Power, M.E. (2000). What enables trophic cascades? Commentary on Polis et al. Trends in Ecology and Evolution 15(11), 443-444.

Preisser, E.L. (2003). Ficld evidence for a rapidly easeading underground food web. Ecology 84(4), 869-874.

Price, P.W., Lewinsohn, T.M., Fernandes, G.W., and Benson, W.W. (1991). "Plant-Animal Interactions, Evolutionary Ecology in Tropical and Temperate Regions." Wiley, New York.

Raven, P.II. and Johnson, G.B. (1996). "Biology." Wm. C. Brown, Dubuque, Iowa.

Readshaw, J.L. (1965). A theory of phasmatid outbreak realease. Australian Journal of Zoology 13, 475-490.

Redford, K.H. (1992). The cmpty forest. BioScience 42(6), 412-422.

Reichle, D.E., Goldstein, R.A., Van Hook, R.I., and Dodson, G.J. (1973). Analysis of inseet consumption in a forest canopy. Ecology 54, 1076-1084.

Reynolds, B.C., Crossley, D.A., and Hunter, M.D. (2003). Response of soil invertebrates to forest canopy inputs along a productivity gradient. Pedobiologia 47, 127-139.

Reynolds, B.C. and Hunter, M.D. (2001). Responses of soil respiration, soil nutrients, and litter decomposition to inputs from canopy herbivores. Soil Biologv and Biochemistry 33(12, 13), 1641-1652.

Reynolds, B.C., Hunter, M.D., and Crosslcy, D.A. (2000). Effects of canopy herbivory on nutrient cycling in a northern hardwood forest in western North Carolina. Selbyana 21(1,2), 74-78.

Ribeiro, S.P. (2003). Insect herbivores in the canopies of savannas and rainforests. In "Arthropods of Tropical Forests" (Y. Basset, V. Novotny, S.E. Miller, and R.L. Kitching, Eds.), pp. 348-359. Cambridge University Press, Cambridge, UK.

Rinker, H.B. (In preparation). The effects of eanopy herbivory on soil microarthropods in a tropical rainforest.

Rinker, H.B., Lowman, M.D., Hunter, M.D., Schowalter, T.D., and Fonte, S.J. (2001). Literature review: canopy herbivory and soil ecology, the top-down impact of torest processes. Selbyana 22(2), 225-231.

Risley, R.S. and Crossley, D.A. (1993). Contribution of herbivore-caused greenfall to litterfall nitrogen flux in several southern Appalachian forested watersheds. American Midland Naturalist 129, 67-74.

Ritchic, M.E., Tilman, D., and Knops, J.M.II. (1998). Herbivore effects on plant and nitrogen dynamies in oak savanna. Ecology 79, 165-177.

Romoser, W.S. and Stoffolano, J.G. (1998). "The Science of Entomology." WCB MeGraw-Hill, Boston, Massachusetts.

Ruess, R.W. and Seagle, S.W. (1994). Landseape patterns in soil microbial processes in the Serengeti National Park, Tanzania. Ecology 75, 892-904.

Schowalter, T.D. (2000). "Inseet Ecology: An Ecosystem Approach." Academic Press, San Diego.

Schowalter, T.D., Hargrove, W.W., and Crossley, D.A. (1986). Herbivory in forested ecosystems. Annual Review of Entomology 31, 177-196.

Schowalter, T.D. and Sabin, T.E. (1991). Litter microarthropod responses to canopy herbivory, season and decomposition in litterbags in a regenerating conifer ecosystem in western Oregon. Biology and Fertility of Soils 11(93-96).

Schowalter, T.D., Sabin, T.E., Stafford, S.G., and Sexton, J.M. (1991). Phytophage effects on primary production, nutrient turnover, and litter decomposition of young Douglas-fir in western Oregon. Forest Ecology and Management 42, 229-243.

Schowalter, T.D., Webb, J.W., and Crossley, D.A. (1981). Community structure and nutrient content of canopy arthropods in clearcut and uncut forest ecosystems. Ecology 62, 1010-1019.

Schultz, A.M. (1964). The nutrient-recovery hypothesis for aretic microtine cycles. II. Ecosystem variables in relation to aretic microtine cycles. In "Grazing in Terrestrial and Marine Environments" (D.J. Crisp, Ed.), pp. 57-68. Blackwell, Oxford, England.

Schultz, J. and Baldwin, I. (1982). Oak leaf quality declines in response to defoliation by gypsy moth larvae. Science 217, 149-151. 
Scastedt, T.R. and Crossley, D.A. (1984). The influence of arthropods on ecosystems. BioScience 34, $157-161$. Selman, B. and Lowman, M.D. (1983). The biology and herbivory rates of Novacastria nothofagi Selman

(Coleoptera: Chrysomclidae), a new genus and species on Nothofagus moorei in Australian temperate rain forests. Australian Journal of Ecology 31, 179-191.

Shaw, Il.E. (1995). The return of the passenger pigeon. Birding 27(3), 223-227.

Smith, A.P. (1982). Diet and feeding strategies of the marsupial sugar glider in temperate Australia. Journal of Animal Ecology 51, 149-166.

Southwood, T.R.E. (1961). The number of speeies of insect associated with various trees. J. Anim. Ecol. $\mathbf{3 0}, 1-8$.

Stadler, B. and Michalzik, B. (2000). Fffeets of phytophagous inseets on micro-organisms and throughfall ehemistry in forested ecosystems: herbivores as switches for the nutrient dynamies in the eanopy. Basic and Applied Ecology 1, 109-116.

Stork, N.E., Adis, J., and Didham, R.K. (Eds.) (1997). "Canopy Arthropods." Chapman and Hall, London. Swank, W.T., Waide, J.B., Crossley Jr., D.A., and Todd, R.L. (1981). Inseet defoliation enhances nitrate export from forest ecosystems. Oecologia 51, 297-299.

Terborgh, J. (1992). "IDiversity and the Tropical Rain Forest." Seientilic Ameriean Library, New York.

Terborgh, John. (1988). The big things that run the world: a sequel to E.O. Wilson. Conservation Biology 2 , $402-403$.

Van Schaik, C.P., Terborgh, J.W., and Wright, S.J. (1993). The phenology of tropical forests: Adaptive significanee and eonsequences for primary consumers. Annual Review of Ecology and Systematics 24, $353-377$.

Ward, D.B. (1979), Rare and Endangered Biota of Florida, Volume Five: Plants, University Press of Florida, Gainesville.

Wardle, D.A. (2002). "Communities and Ecosystems: Linking the Aboveground and Belowground Components." Princeton University Press, Princeton.

Whittman, T.G. (1981). Individual trees at heterogeneous environments: Adaptation to herbivory or epigenetic noise? In "Species and Life History Patterns: Geographic and Habitat Variations" (R.F. Denno and II. Dingle, Eds.), pp. 9-27. Springer, New York.

Wilcove, D. (1989). In memory of Martha and her kind. Audubon September, 52-55.

Wilson, E.O. (1987a). The little things that run the world: The importanee and conservation of invertebrates. Conservation Biology 1, 344-346.

Wilson, E.O. (1987b). The earliest known ants: $\Lambda$ n analysis of the Cretaceous species and an inference coneerning their social organization. Paleobiology 1.3(1), 44-53.

Wilson, E.O. (1992). "The Diversity of Life." Belknap Press of Ilarvard University Press, Cambridge, MA. Wint, G.R.W. (1983). Leaf damage in tropical rain forest canopies. In "Tropical Rain Forest: Ecology and Management" (S.L. Sutton, T.C. Whitmore, and A.C. Chadwick, Eds.), pp. 229-240. Blackwell, Oxford, UK. Woinarski, J.C.Z. and Cullen, J.M. (1984). Distribution of invertebrates on foliage in forests of southeastern Australia. Australian Journal of Ecology 9, 207-23,3. 